\title{
DRIFT-ARID: Application of a method for environmental water requirements (EWRs) in a non-perennial river (Mokolo River) in South Africa
}

\author{
Maitland Seaman', Marie Watson', Marinda Avenant ${ }^{1 *}$, Alison Joubert ${ }^{2}$, Jackie King ${ }^{3}$, Charles Barker ${ }^{4}$, Surina \\ Esterhuyse', Douglas Graham5 ${ }^{5}$, Marthie Kemp' ${ }^{1}$, Pieter le Roux ${ }^{6}$, Bob Prucha7, Nola Redelinghuys ${ }^{8}$, Linda \\ Rossouw $^{9}$ Kate Rowntree ${ }^{10}$, Frank Sokolic ${ }^{1}$, Leon van Rensburg ${ }^{6}$, Bennie van der Waal ${ }^{10}$, Johan van Tol ${ }^{11}$ and \\ Tascha Vos ${ }^{1}$ \\ ${ }^{1}$ Centre for Environmental Management, University of the Free State, PO Box 339, Bloemfontein, South Africa \\ ${ }^{2}$ Southern Waters, PO Box 12414, Cape Town, South Africa \\ ${ }^{3}$ Water Matters, PO Box 209, Constantia, South Africa \\ ${ }^{4}$ Geography Department, University of the Free State, PO Box 339, Bloemfontein, South Africa \\ ${ }^{5} \mathrm{DHI}$, Agern Allé 5, DK-2970 Hørsholm, Denmark \\ ${ }^{6}$ Soil, Crop and Climate Sciences Department, University of the Free State, PO Box 339, Bloemfontein, South Africa \\ ${ }^{7}$ DHI Water \& Environment, 141 Union Blvd, Suite 425, Lakewood, USA \\ ${ }^{8}$ Department of Sociology, University of the Free State, PO Box 339, Bloemfontein, South Africa \\ ${ }^{9}$ Environmental and Water Quality Consultant, PO Box 16018, Panorama, 7506, South Africa ${ }^{10}$ Geography Department, Rhodes University, PO Box 94, \\ Grahamstown, South Africa \\ ${ }^{11}$ University of Fort Hare, Private Bag X1314, Alice, South Africa.
}

\begin{abstract}
Methods developed to determine the amount of water required (EWR) to sustain ecosystem services in non-perennial rivers need a different approach to those used in perennial rivers. Current EWR methods were mostly developed for use in perennial rivers. Non-perennial rivers differ from perennial ones in terms of variability in flow, periods of no-flow and related habitat availability. A DRIFT-ARID method (an adaptation of the Downstream Response to Imposed Flow Transformation (DRIFT) method) was developed, tested and adjusted, using the semi-permanent Mokolo River. Field data from five study sites was collected from April to May 2010 by a multidisciplinary team. The results were used in a DRIFT-ARID Decision Support System (DSS) to determine the impact of five chosen development scenarios in the Mokolo River Catchment. An integrated groundwater-surface water MIKE-SHE hydrological model was used to simulate the hydrology of the chosen scenarios. Specific non-perennial river indicators such as onset of dry phase were identified and included in the DRIFT-ARID DSS. DRIFT-ARID has the potential to be used in non-perennial rivers and, once set up, can provide results for future scenarios. The method now needs to be tested on other non-perennial river types, especially episodic rivers where data are scarce or non-existent.
\end{abstract}

ABSTRACT

Keywords: DRIFT-ARID, non-perennial, EWR, flow method, Mokolo River

\section{INTRODUCTION}

EWR methods to determine the amount of water required to sustain ecosystem services in non-perennial rivers need to be adapted from those currently being used in perennial rivers. South Africa's National Water Act (No. 36 of 1998) requires the proclamation of environmental Reserves before licences are issued for water use. Water abstraction from rivers is regulated by relevant government authorities to ensure equity of use for all users.

In generic perennial EWR determinations, a hydrological time series of data is the starting point (Brown and Louw, 2011). The methods use data on low and high flows which is then related to hydraulics and the response of biota in the river (King et al., 2004). In perennial rivers, flow is continuous and community composition of biota is spatially structured (Bunn and Arthington, 2002). The observed (present day) conditions are compared to the reference (natural) conditions when the present state of the river is determined (Kleynhans and Louw, 2007).

\footnotetext{
* To whom all correspondence should be addressed.

ฮ 051401 3939; e-mail: avenantmf@ufs.ac.za

Received 30 March 2015; accepted in revised form 25 May 2016
}

A non-perennial river's hydrology differs from that of a perennial river, as each is hydrologically distinctive with highly variable runoff having a high coefficient of variance $(\mathrm{CV})$, mostly $>1$ (Bull and Kirkby, 2002; Thoms and Sheldon, 2002) and a high hydrological index, which is calculated from a combination of monthly CVs (standard deviation/mean) and an estimate of the contribution that baseflows make to total flows (Hughes and Hannart, 2003). The rivers are mostly event-driven and subject to constant and sometimes extreme fluctuations in hydrology and other physical conditions (Uys, 1998). Sediment loads are also high, with relatively high proportions of bedload compared to humid-area perennial rivers (Bull and Kirkby, 2002). The high variability of non-perennial rivers means that many rivers exhibit disequilibrium, so it may not be possible to apply the general hydraulic geometry relationships established for perennial systems (Rowntree and Van der Waal, 2012). The fauna are unstructured (spatial patterns are less clear), physically controlled and under constant stress (Uys, 1998).

EWR methods, used to determine the Reserve, were developed on perennial rivers. Projects funded by the Water Research Commission (WRC) to test if these methods were suitable for use on non-perennial rivers revealed certain deficiencies and found that they could not always be applied to 


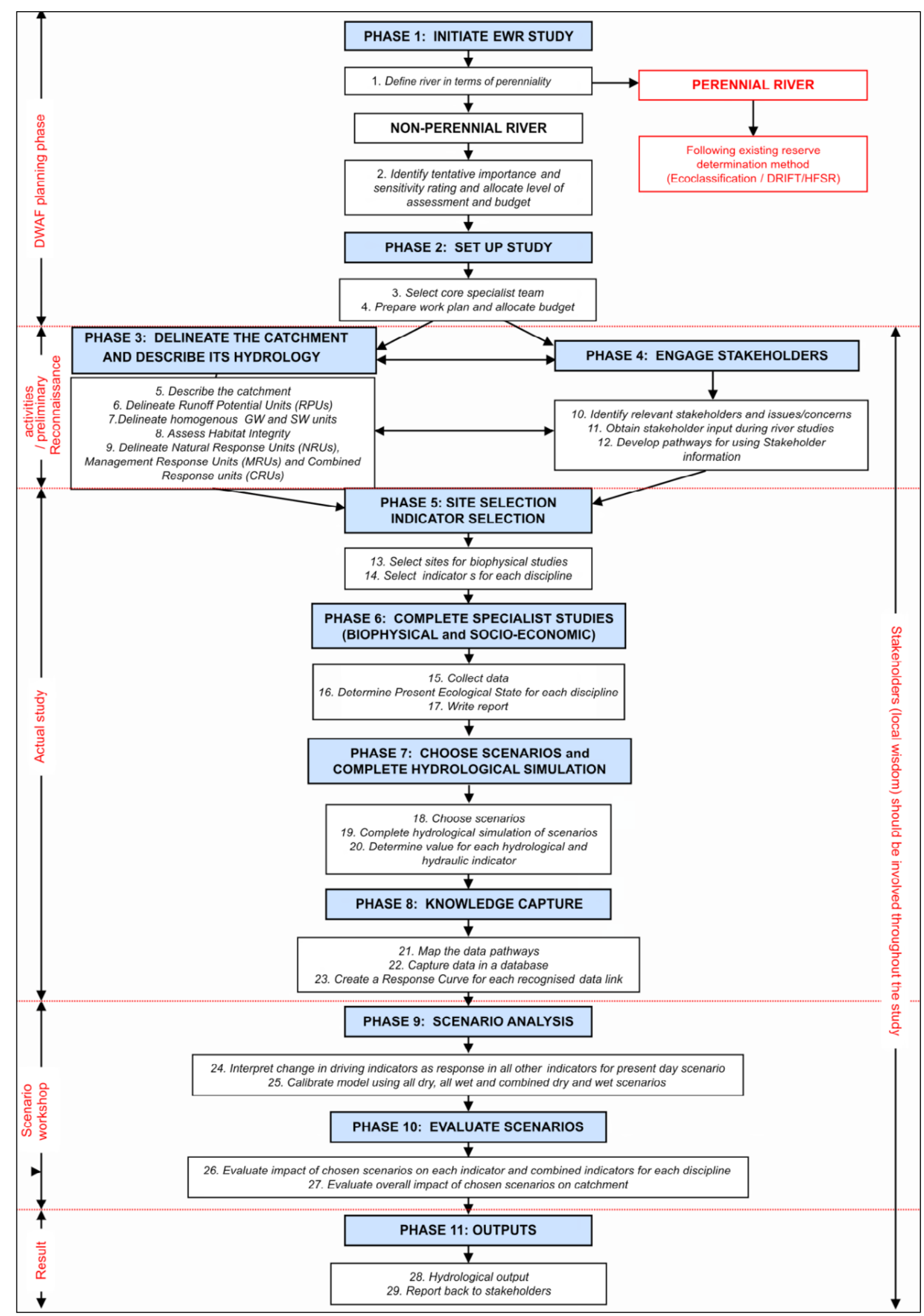

Figure 1

DRIFT-ARID method for determining the EWR of a non-perennial river 
non-perennial rivers in their present form (Rossouw et al., 2005; Seaman et al., 2010).

Current perennial EWR methods used in South Africa, namely, DRIFT (Brown et al., 2008; 2013) and Habitat Flow Stressor Response (HFSR, O'Keeffe et al., 2002), as well as Ecoclassification (Kleynhans and Louw, 2007) which is an integral part of EWR methods, were therefore evaluated in this study to determine if they could be suitable for use in non-perennial rivers. It was found that the DRIFT method could be used and modified where necessary.

The original DRIFT method (King et al., 2004) was adjusted, in the study on the Mokolo River, and the application of the adapted method named DRIFT-ARID was tested (for details see Seaman et al., 2013; 2016).

The DRIFT-ARID method includes some aspects which differ from the original DRIFT method (King et al., 2004) and other perennial methods, of which the most important are:

- The addition of new flow and hydraulic indicators which are relevant for non-perennial systems, such as 'onset of hydrological wet season after a period of wet river bed', 'depth to groundwater,' 'percentage contribution of groundwater to surface flow'

- The creation of weighted (as opposed to un-weighted) lag periods, such that more recent results have a greater influence than those further in the past (now incorporated in the original DRIFT method)

- The DRIFT-ARID method was the first test of the use of DRIFT's 'linked indicators', whereby response indicators are linked to driver indicators other than flow (e.g. a fish indicator linked to a macroinvertebrate indicator as a source of food)

- The inclusion of the use of an integrated groundwater and surface water hydrological model to produce data on indicators needed such as \% contribution of groundwater to surface flow in dry periods

Only phases and activities in the DRIFT-ARID method that differ from the original DRIFT or perennial EWR methods will be discussed.

\section{IMPLEMENTATION OF METHOD}

The DRIFT-ARID method tested comprises 11 phases and 29 activities as illustrated in Fig. 1 (see Seaman et al., 2016).

The phases and activities in the DRIFT-ARID method (see Seaman et al., 2013; 2016) were completed using the Mokolo River, South Africa, as a case study (Fig. 2). Only selected phase results will be presented (for complete results, see Seaman et al., 2013).

\begin{tabular}{|l|c|c|l|}
\hline \multicolumn{4}{|c|}{ TABLE 1 } \\
\hline Degree of non-perenniality of the Mokolo River \\
\hline $\begin{array}{c}\text { Locality of time } \\
\text { when there is } \\
\text { flow }\end{array}$ & $\begin{array}{c}\text { \#Gauging } \\
\text { station }\end{array}$ & $\begin{array}{l}\text { Type of non- } \\
\text { perennial river }\end{array}$ \\
\hline $\begin{array}{l}\text { Mokolo at } \\
\text { Dwaalhoek }\end{array}$ & $72 \%$ & A4H005 & $\begin{array}{l}\text { On the border of } \\
\text { semi-permanent } \\
\text { and ephemeral }\end{array}$ \\
\hline $\begin{array}{l}\text { Mokolo at } \\
\text { Zandrivier }\end{array}$ & $87 \%$ & A4H002 & Semi-permanent \\
\hline
\end{tabular}

\# for location of gauging station see Fig. 2.

\section{Phase 1: Initiate the EWR Study}

The degree of non-perenniality of the catchment was determined by Steÿn (2008), using daily flow data from two functioning gauging weirs (A4H002; A4H005; Fig. 2) with reliable data available from the Department of Water and Sanitation (DWS). The measure of non-perenniality is important when deciding which specialists are required in the team. The Mokolo River is a semipermanent river with sections bordering on ephemeral (Table 1). As this is a semi-permanent river, the multidisciplinary team of specialists included hydrological modellers; geomorphologists; water quality, vegetation, fish and macroinvertebrate specialists; a DSS modeller; a sociologist; soil scientists; a geohydrologist and a GIS specialist.

\section{Phase 3: Delineate the catchment and describe its hydrology}

Detailed desktop data and information on the Mokolo River catchment was collected by the team to define the catchment. Runoff Potential Units (RPUs) were determined using drainage features, slope, cover, soil composition and rainfall intensity data, following the method in Barker (2010). The Mokolo is a fifthorder (Strahler's ordering; Strahler, 1952) catchment with 48 third-order catchments forming the RPUs. The highest potential runoff will occur mostly in the southern and eastern part of the catchment as the result of low cover, steeper slopes, and higher rainfall intensity (Fig. 3).

Natural Resource Units (NRUs), Management Resource Units (MRUs) and Combined Resource Units (CRUs) were identified using a GIS method of overlays (Seaman et al., 2013). The combination of NRUs and MRUs into CRUs is a unique step in the DRIFT-ARID method and is not followed in the perennial method (Kleynhans and Louw, 2007a).

NRUs were determined by overlaying Geomorphological Zones, Macroreaches and Level II Ecoregions (Fig. 4 left) with the RPUs (Fig. 3). Seven NRUs (A-G) were identified (Fig. 4 right).

Seven MRUs (A-G) were identified in the Mokolo Catchment by overlaying maps containing information from the Water Quality Response Units (WQRUs), Socio-Economic Response Units (SRUs) and Habitat Integrity Units (HIUs) (Fig. 5 left and right). A combination of the three maps provides an understanding of the catchment in relation to the impacts and future developments planned for the catchment.

An overlay of NRUs and MRUs produced nine CRUs (A-I) which represent units in the Mokolo River that are relatively homogenous with regards to natural and management aspects (Fig. 6).

Once the CRUs were chosen, they needed to be ranked in importance by each specialist. Rankings were then combined to obtain a final, overall ranking, with the lowest score indicating the most critical or important CRU. Different CRUs could have the same ranking and it was therefore necessary to standardise the ranking from each specialist to produce the same total throughout. The nine identified CRUs for the Mokolo River were ranked from 1 (important) to 9 (not important), and standardised to ensure each specialist's ranking totalled 45 $(1+2+3+4+\ldots 9=45)$. In this case, CRU H was the most critical (Table 2). 


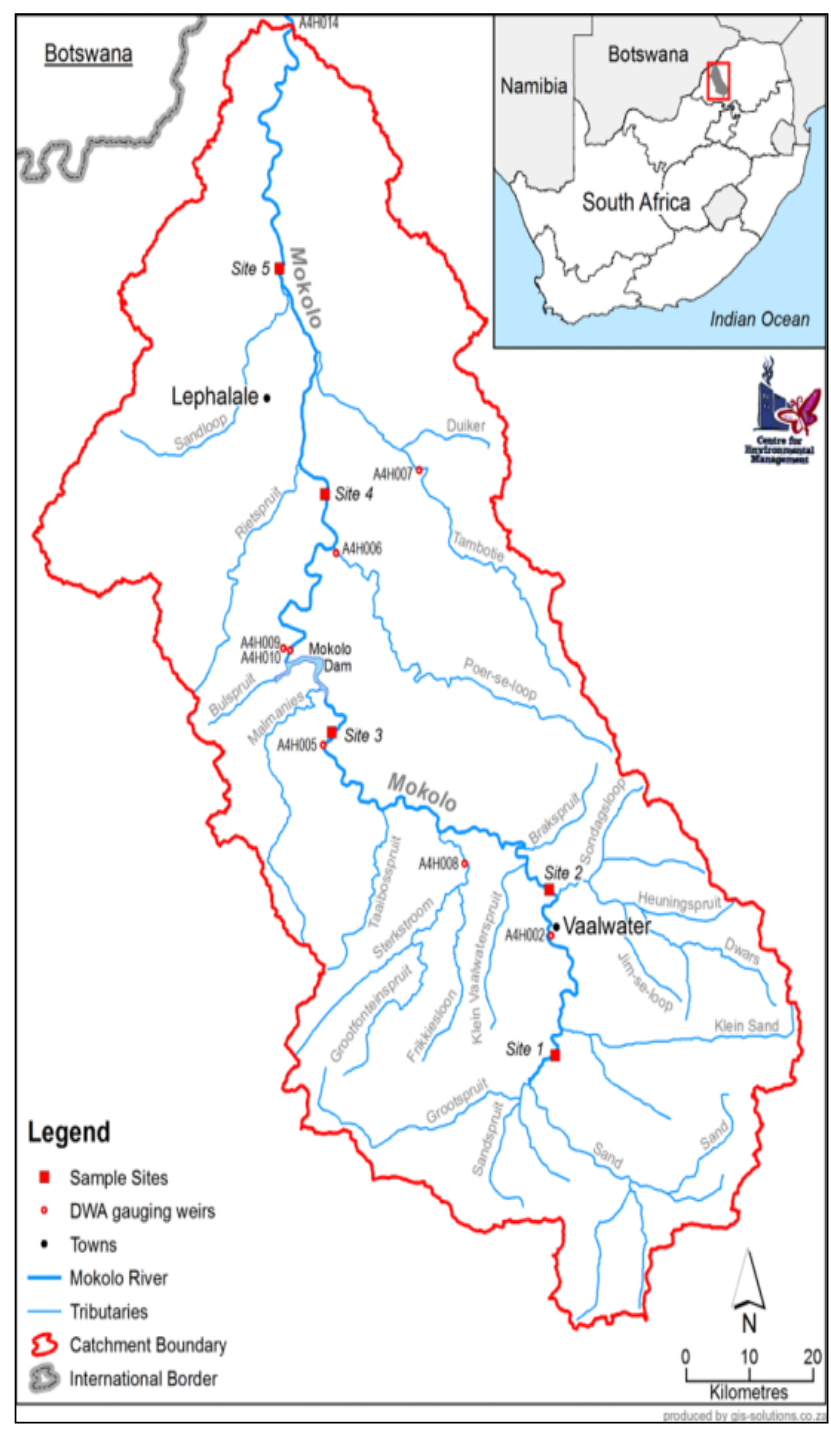

Figure 2

Location of Mokolo River including tributaries, towns and Department of Water and Sanitation (DWS) gauging stations and sites

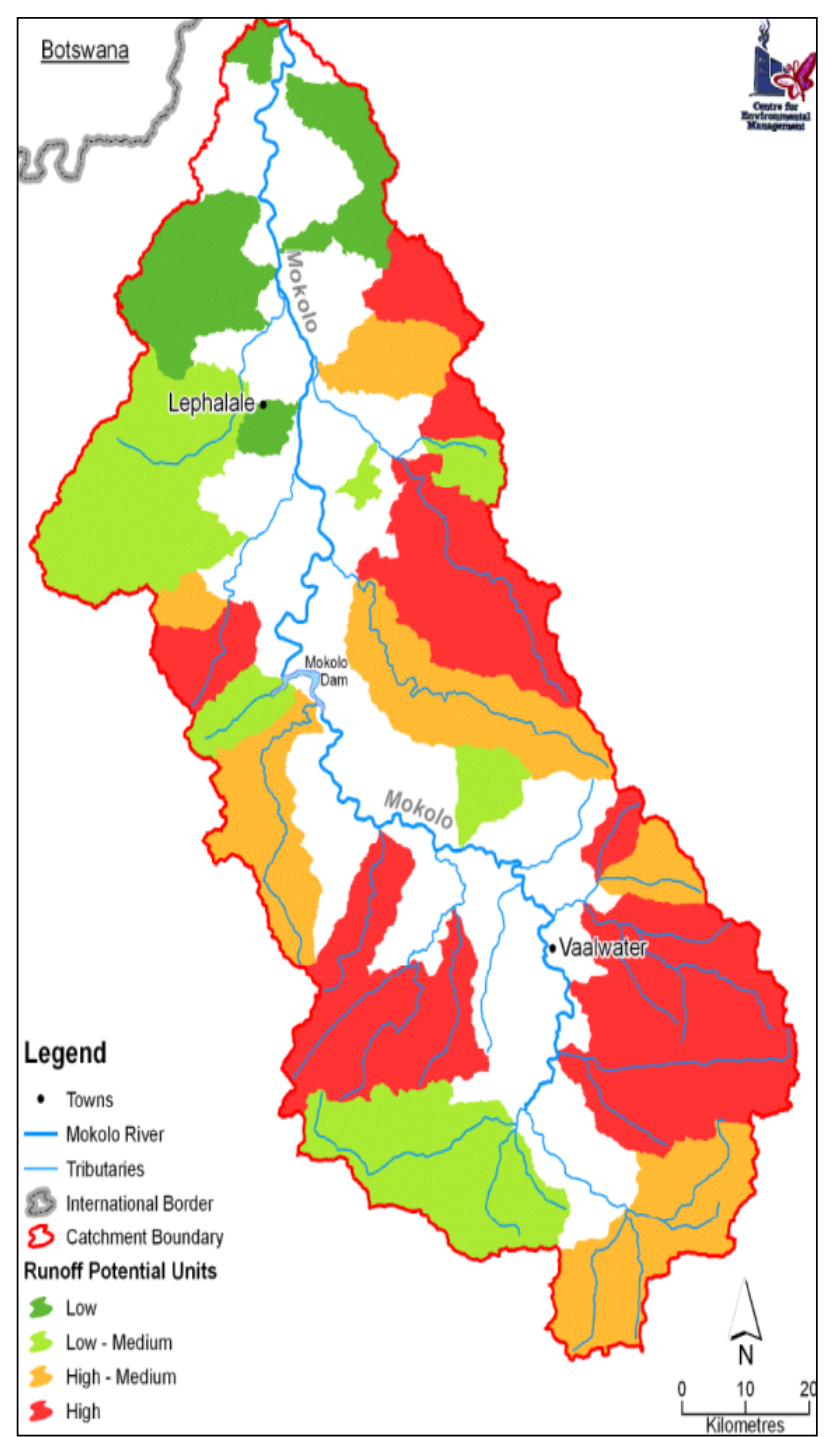

Figure 3

Runoff Potential Units (RPUS) in Mokolo River catchment (white areas represent stream orders other than third order used for RPU determination)

TABLE 2

Combined and standardised combined specialist Combined Resource Unit (CRU) ranking in the Mokolo River in terms of importance for sampling

\begin{tabular}{|c|c|c|c|c|c|c|c|c|c|c|c|c|c|c|c|c|c|c|c|c|}
\hline \multicolumn{14}{|c|}{ tance for sa } & & & & & & & \\
\hline \multirow[t]{2}{*}{ CRU } & \multicolumn{2}{|c|}{$\begin{array}{l}\text { Water } \\
\text { quality }\end{array}$} & \multicolumn{2}{|c|}{ Soil } & \multicolumn{2}{|c|}{ Fish } & \multicolumn{2}{|c|}{$\begin{array}{l}\text { Macro- } \\
\text { inverte- } \\
\text { brates }\end{array}$} & \multicolumn{2}{|c|}{$\begin{array}{l}\text { Vegeta- } \\
\text { tion }\end{array}$} & \multicolumn{2}{|c|}{$\begin{array}{l}\text { Fluvial } \\
\text { geomor- } \\
\text { phology }\end{array}$} & \multicolumn{2}{|c|}{$\begin{array}{c}\text { Catch- } \\
\text { ment } \\
\text { geomor- } \\
\text { phology }\end{array}$} & \multicolumn{2}{|c|}{$\begin{array}{l}\text { Socio- } \\
\text { economic }\end{array}$} & \multicolumn{2}{|c|}{ Score } & \multicolumn{2}{|c|}{ Final rank } \\
\hline & 0 & $S$ & 0 & $S$ & 0 & $S$ & 0 & $S$ & 0 & $S$ & 0 & $S$ & 0 & $S$ & 0 & $S$ & 0 & $S$ & 0 & $S$ \\
\hline $\mathrm{H}$ & 2.0 & 6.0 & 1.0 & 2.0 & 5.0 & 5.0 & 1.0 & 1.0 & 2.0 & 3.5 & 1.0 & 1.0 & 5.0 & 5.0 & 1.0 & 1.0 & 18.0 & 24.5 & 1.0 & 1.0 \\
\hline D & 2.0 & 6.0 & 1.0 & 2.0 & 3.0 & 3.0 & 2.0 & 2.0 & 2.0 & 3.5 & 5.0 & 5.0 & .0 & 7.5 & 2.0 & 2.0 & 23.0 & 1.0 & .0 & 2.0 \\
\hline $\mathbf{G}$ & 1.0 & 2.5 & 3.0 & 5.0 & 4.0 & 4.0 & 3.0 & 3.0 & 2.0 & 3.5 & 4.0 & 4.0 & 5.0 & 5.0 & 8.0 & 8.0 & 30.0 & 35.0 & 3.0 & 3.0 \\
\hline B & 1.0 & 2.5 & 9.0 & 8.0 & 1.0 & 1.0 & 6.0 & 6.0 & 6.0 & 8.0 & 7.0 & 7.0 & 2.0 & 1.0 & 4.0 & 4.0 & 36.0 & 37.5 & 6.0 & 4.0 \\
\hline $\mathbf{E}$ & 1.0 & 2.5 & 3.0 & 5.0 & 7.0 & 7.0 & 8.0 & 8.0 & 1.0 & 1.0 & 3.0 & 3.0 & 6.0 & 7.5 & 7.0 & 7.0 & 36.0 & 41.0 & 5.0 & 5.0 \\
\hline C & 2.0 & 6.0 & 9.0 & 8.0 & 2.0 & 2.0 & 7.0 & 7.0 & 5.0 & 7.0 & 2.0 & 2.0 & 7.0 & 9.0 & 3.0 & 3.0 & 35.0 & 44.0 & 4.0 & 6.0 \\
\hline $\mathbf{F}$ & 1.0 & 2.5 & 3.0 & 5.0 & 8.0 & 8.0 & 9.0 & 9.0 & 2.0 & 3.5 & 9.0 & 9.0 & 3.0 & 2.5 & \begin{tabular}{|l|}
6.0 \\
\end{tabular} & 6.0 & 41.0 & 45.5 & \begin{tabular}{|l|}
8.0 \\
\end{tabular} & 7.0 \\
\hline I & 4.0 & 8.5 & $\begin{array}{l}1.0 \\
\end{array}$ & 2.0 & 6.0 & 6.0 & 4.0 & 4.0 & 3.0 & 6.0 & 6.0 & 6.0 & 5.0 & 5.0 & 9.0 & 9.0 & 38.0 & 46.5 & 7.0 & 8.0 \\
\hline A & \begin{tabular}{|l|}
4.0 \\
\end{tabular} & 8.5 & \begin{tabular}{|l|}
9.0 \\
\end{tabular} & 8.0 & \begin{tabular}{|l|}
9.0 \\
\end{tabular} & 9.0 & 5.0 & 5.0 & \begin{tabular}{|l|}
7.0 \\
\end{tabular} & 9.0 & \begin{tabular}{|l|}
8.0 \\
\end{tabular} & 8.0 & 3.0 & 2.5 & \begin{tabular}{|l|}
5.0 \\
\end{tabular} & 5.0 & 50.0 & 55.0 & 9.0 & 9.0 \\
\hline TOT & & 45.0 & & 45.0 & & 45.0 & & 45.0 & & 45.0 & & 45.0 & & 45.0 & & 45.0 & & & & \\
\hline
\end{tabular}

$(\mathrm{O}=$ original specialist ranking, $S=$ standardised ranking) 


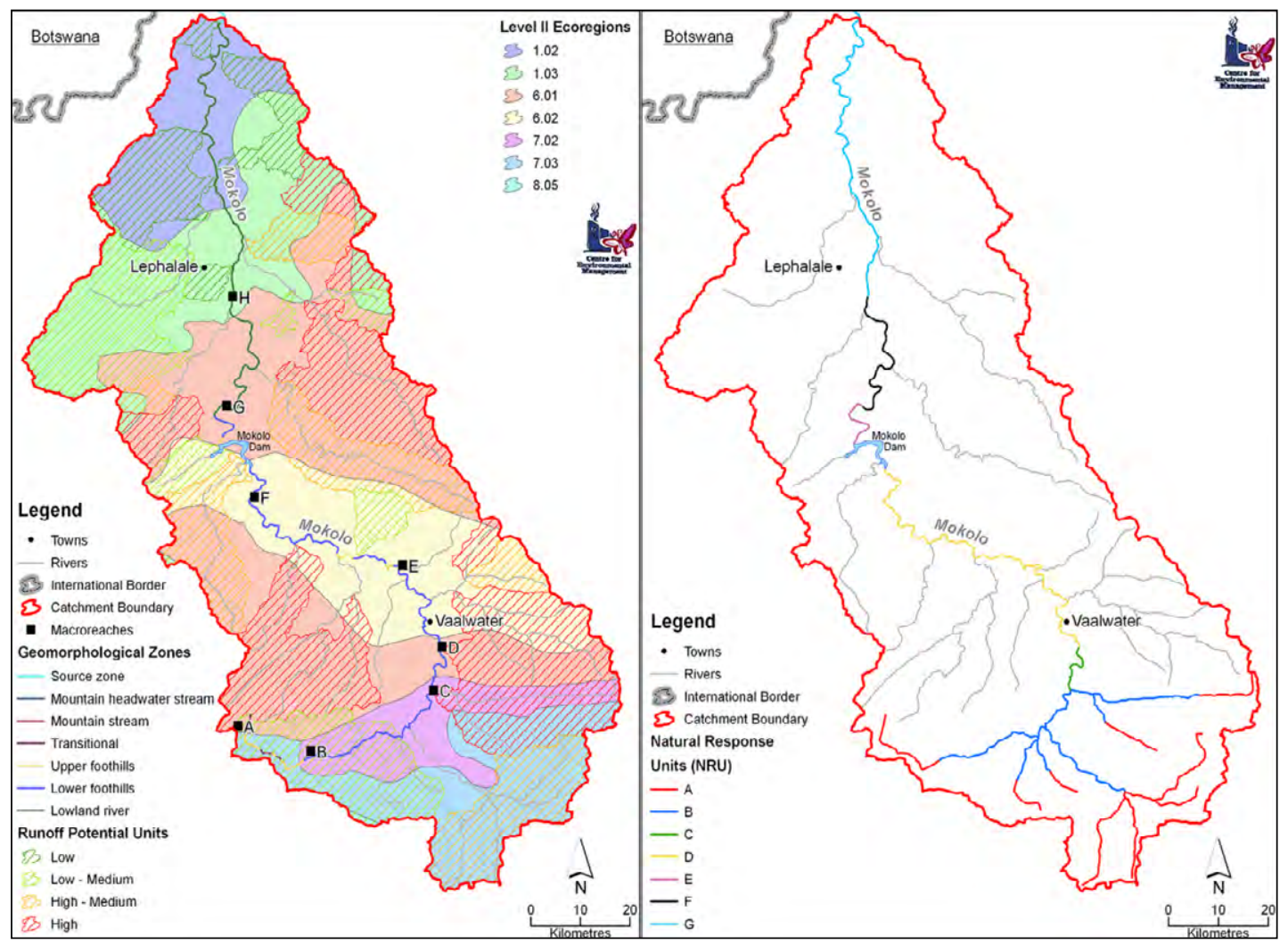

Figure 4

Left: Overlay of Geomorphological Zones, Macroreaches, Level II Ecoregions, and Runoff Potential Units (RPUs). Right: Natural Resource Units (NRUs) identified in the Mokolo River.

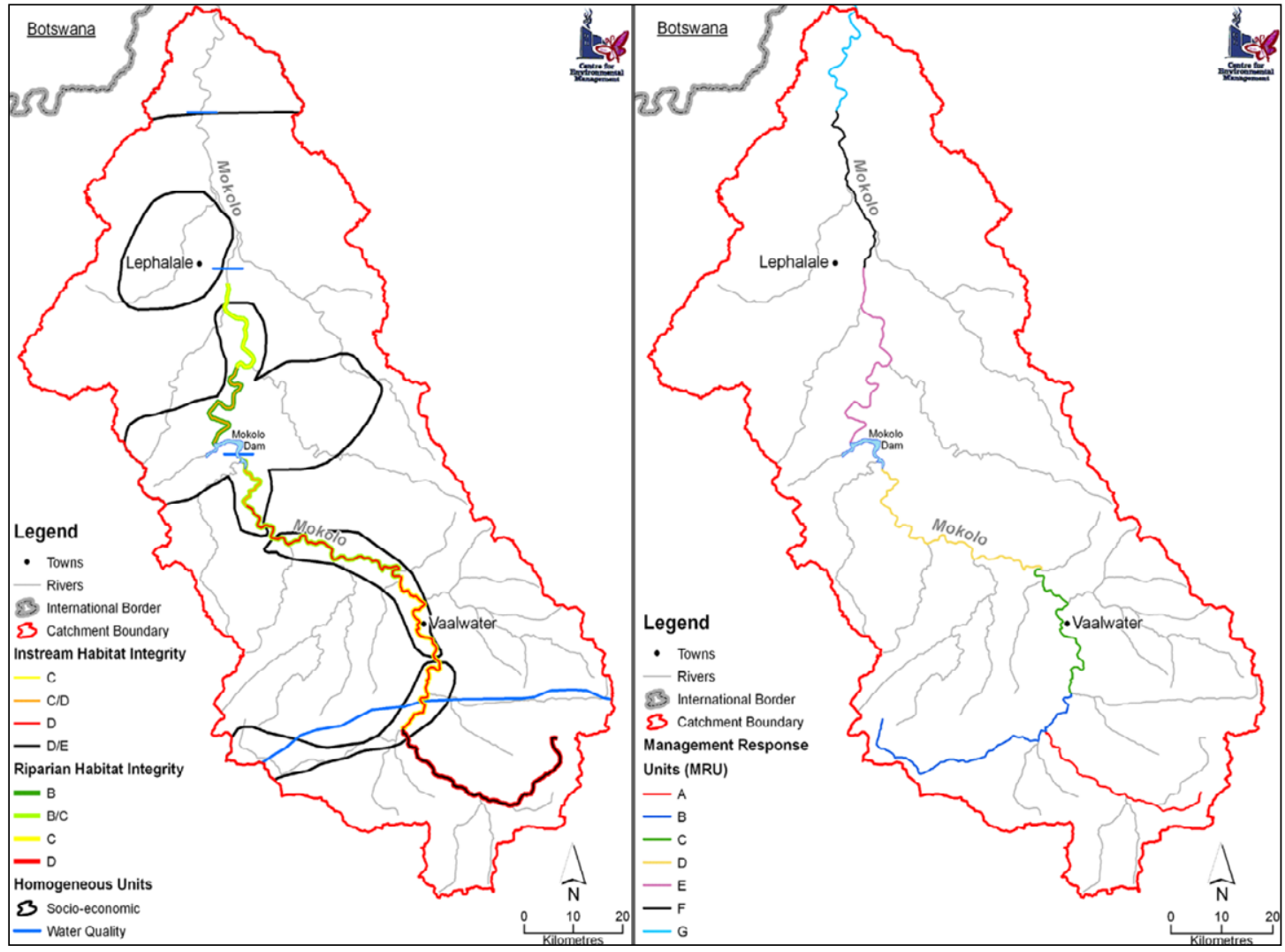

Figure 5

Left: overlay of Water Quality Response Units (WQRUs), Socio-Economic Response Units (SRUs) and Habitat Integrity Units (HIUs). Right: Management Resource Units (MRUS) (A-G) identified in the Mokolo River 
TABLE 3

All indicators and their linked indicators as defined for the Mokolo River; indicators chosen for non-perennial rivers or specific scenarios appear in bold italics

\begin{tabular}{|c|c|c|c|c|c|c|c|c|c|}
\hline & & & & & & & & & \\
\hline Give & coue & IIUicator & Linins & & & & & & \\
\hline \multirow{17}{*}{$\begin{array}{l}\frac{n}{0} \\
\stackrel{0}{0} \\
.0 \\
0.0 \\
\vdots \\
\vdots \\
0 \\
\frac{0}{4}\end{array}$} & $\mathrm{H} 1$ & Total annual volume of surface flow (MAR) & & & & & & & \\
\hline & $\mathrm{H} 2 \mathrm{a}$ & Depth of water table: channel, dry & & & & & & & \\
\hline & $\mathrm{H} 2 \mathrm{~b}$ & Depth of water table: channel, wet & & & & & & & \\
\hline & H3a & \% contribution of groundwater to surface flow, dry & & & & & & & \\
\hline & $\mathrm{H} 3 \mathrm{~b}$ & $\%$ contribution of groundwater to surface flow, wet & & & & & & & \\
\hline & H5 & Onset of surface flow after period of dry river bed & & & & & & & \\
\hline & H6 & Onset of hydro wet season after a period of wet river bed & & & & & & & \\
\hline & $\mathrm{H} 7$ & No. of floods per year that cover FZ1 & & & & & & & \\
\hline & $\mathrm{H} 8$ & No. of floods per year that cover FZ2 & & & & & & & \\
\hline & H9 & Longest duration of inundation of FZ2 & & & & & & & \\
\hline & $\mathrm{H} 10$ & No. of floods per year that enter FZ3 & & & & & & & \\
\hline & H11 & Flood greater than PD 1.3 magnitude & & & & & & & \\
\hline & $\mathrm{H} 12$ & Peak flow discharge & & & & & & & \\
\hline & $\mathrm{H} 13$ & Surface flow duration & & & & & & & \\
\hline & H14 & No surface flow onset & & & & & & & \\
\hline & H15 & No surface flow duration & & & & & & & \\
\hline & $\mathrm{H} 16$ & Channel subsurface flow, dry & & & & & & & \\
\hline \multirow{5}{*}{ 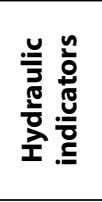 } & Hyl & Height of max. flood per year & & & & & & & \\
\hline & Hy2 & Length of time with flow $<0.3$ & & & & & & & \\
\hline & Hy3 & Length of time with flow $>0.3$ & & & & & & & \\
\hline & Hy4 & Average depth: dry season & & & & & & & \\
\hline & Hy5 & Average depth: wet season & & & & & & & \\
\hline \multirow{5}{*}{ 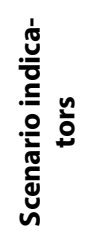 } & P1 & Pollution & & & & & & & \\
\hline & S1 & Ratio: fine to coarse & & & & & & & \\
\hline & Sc1 & Hectares of cultivated land & & & & & & & \\
\hline & $\mathrm{Sc} 2$ & Hectares of game farms & & & & & & & \\
\hline & Sc3 & Power produced by power plants & & & & & & & \\
\hline \multirow{10}{*}{ 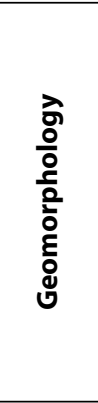 } & G1 & Percent of fines (sand and smaller) on bed & $\mathrm{H} 8$ & S1 & & & & & \\
\hline & G2 & Width of low-flow channel & $\mathrm{H} 8$ & $\mathrm{H} 12$ & S1 & $\mathrm{V} 2$ & & & \\
\hline & G3 & Low-flow channel depth & $\mathrm{H} 8$ & $\mathrm{H} 12$ & S1 & & & & \\
\hline & G4 & Geomorphic pool depth & $\mathrm{H} 8$ & $\mathrm{H} 12$ & S1 & V3 & & & \\
\hline & G5 & Length of pools & $\mathrm{H} 8$ & $\mathrm{H} 12$ & $\mathrm{~V} 2$ & & & & \\
\hline & G6 & Area of Flood Zone 1 & G2 & & & & & & \\
\hline & G7 & Area of Flood Zone 2 & G2 & V3 & & & & & \\
\hline & G8 & Area of Flood Zone 3 & H12 & & & & & & \\
\hline & G9 & Number of low-flow channels & S1 & V2 & & & & & \\
\hline & G10 & Geomorphic number of floods covering FZ3 & G3 & & & & & & \\
\hline \multirow{9}{*}{ 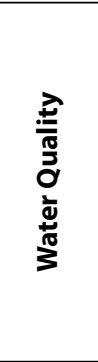 } & WQ1 & Conductivity (flowing state) & $\mathrm{H} 3 \mathrm{a}$ & $\mathrm{H} 3 \mathrm{~b}$ & $\mathrm{H} 10$ & $\mathrm{H} 13$ & $\mathrm{P} 1$ & & \\
\hline & WQ2 & $\mathrm{pH}$ (flowing state) & $\mathrm{H} 3 \mathrm{a}$ & $\mathrm{H} 3 \mathrm{~b}$ & $\mathrm{H} 10$ & H13 & $\mathrm{P} 1$ & & \\
\hline & WQ3 & Nutrients (flowing state) & $\mathrm{H} 3 \mathrm{a}$ & $\mathrm{H} 3 \mathrm{~b}$ & $\mathrm{H} 10$ & $\mathrm{H} 13$ & $\mathrm{P} 1$ & & \\
\hline & WQ5 & Algae/ Chlorophyll $a$ (flowing state) & $\mathrm{H} 3 \mathrm{a}$ & $\mathrm{H} 3 \mathrm{~b}$ & $\mathrm{H} 10$ & $\mathrm{H} 13$ & $\mathrm{P} 1$ & & \\
\hline & WQ6 & Conductivity (isolated pools) & $\mathrm{H} 3 \mathrm{a}$ & $\mathrm{H} 3 \mathrm{~b}$ & $\mathrm{H} 10$ & H16 & P1 & & \\
\hline & WQ7 & pH (isolated pools) & $\mathrm{H} 3 \mathrm{a}$ & $\mathrm{H} 3 \mathrm{~b}$ & $\mathrm{H} 10$ & H16 & P1 & & \\
\hline & WQ8 & Nutrients (isolated pools) & $\mathrm{H} 3 \mathrm{a}$ & $\mathrm{H} 3 \mathrm{~b}$ & $\mathrm{H} 10$ & H16 & $\mathrm{P} 1$ & & \\
\hline & WQ10 & Algae/Chlorophyll a (isolated pools) & $\mathrm{H} 3 \mathrm{a}$ & $\mathrm{H} 3 \mathrm{~b}$ & $\mathrm{H} 10$ & H13 & P1 & & \\
\hline & WQ11 & Microbiological pollution: E. coli, cholera, etc. & $\mathrm{H} 3 \mathrm{a}$ & $\mathrm{H} 3 \mathrm{~b}$ & $\mathrm{H} 10$ & $\mathrm{H} 13$ & $\mathrm{P} 1$ & & \\
\hline \multirow{5}{*}{ 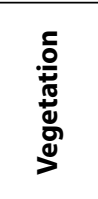 } & V1 & Aquatic vegetation & H5 & H6 & H13 & Hy5 & WQ8 & & \\
\hline & V2 & Marginal vegetation & $\mathrm{H} 2 \mathrm{a}$ & $\mathrm{H} 12$ & $\mathrm{H} 15$ & Hy5 & S1 & & \\
\hline & V3 & Lower bank vegetation & $\mathrm{H} 2 \mathrm{a}$ & $\mathrm{H} 8$ & H15 & S1 & & & \\
\hline & $\mathrm{V} 4$ & Upper bank vegetation & $\mathrm{H} 2 \mathrm{a}$ & H10 & S1 & & & & \\
\hline & V5 & Floodplain vegetation (switched off at Site 4) & $\mathrm{H} 2 \mathrm{a}$ & $\mathrm{H} 2 \mathrm{~b}$ & $\mathrm{H} 8$ & H10 & S1 & & \\
\hline
\end{tabular}




\begin{tabular}{|c|c|c|c|c|c|c|c|c|c|}
\hline \multicolumn{10}{|c|}{$\begin{array}{l}\text { TABLE } 3 \text { (CONTINUED) } \\
\text { All indicators and their linked indicators as defined for the Mokolo River; indicators chosen for non-perennial rivers or specific } \\
\text { scenarios appear in bold italics }\end{array}$} \\
\hline \multirow{3}{*}{ 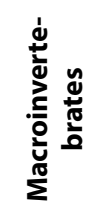 } & I1 & Riffle/rapid families (incl. rocky interpools) & H5 & H13 & H14 & H15 & Hy5 & Hy2 & Hy3 \\
\hline & $\mathrm{I} 2$ & Pool and open sandy beds families & H15 & H16 & Hy4 & G1 & WQ6 & WQ10 & \\
\hline & I3 & Aquatic and marginal vegetation families & WQ5 & WQ10 & V1 & V2 & & & \\
\hline \multirow{3}{*}{ 产 } & F1 & Rapid/riffle-dwelling fish species & $\mathrm{H} 5$ & H9 & $\mathrm{H} 13$ & $\mathrm{H} 14$ & Hy4 & G1 & WQ5 \\
\hline & F2 & Deep pool-dwelling species & $\mathrm{H} 8$ & H15 & Hy5 & G1 & WQ6 & WQ10 & $\mathrm{V} 2$ \\
\hline & F3 & Shallow pool-dwelling species & $\mathrm{H} 9$ & $\mathrm{H} 15$ & Hy4 & G7 & WQ10 & V1 & V2 \\
\hline \multirow{6}{*}{ 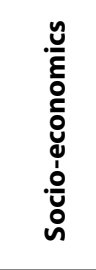 } & SE1 & Employment & Sc1 & $\mathrm{Sc} 2$ & Sc3 & & & & \\
\hline & SE2 & Household income & Sc1 & $\mathrm{Sc} 2$ & $\mathrm{Sc} 3$ & & & & \\
\hline & SE3 & Tourist numbers & Sc2 & WQ11 & \multicolumn{5}{|c|}{ Ecosystem integrity } \\
\hline & SE4 & Incidence of diarrhoea in under-5-year-olds & $\mathrm{P} 1$ & WQ11 & & & & & \\
\hline & SE5 & Pesticide poisoning & P1 & Sc1 & \multicolumn{5}{|c|}{ Ecosystem integrity } \\
\hline & SE6 & Impacts of floods and droughts & WQ5 & WQ5 & WQ1 & & & & \\
\hline
\end{tabular}

\section{Phase 5: Site and indicator selection}

Sites and indicators were selected by the team:

- Site selection: Five sites were identified in each of the five most important CRUs (H; D; G; B and E, Fig. 6). The location of the sites was determined using data on existing sites already sampled as part of the River Health Programme (DWA 2010b), routine fish sampling sites (Kleynhans et al., 2008), and Intermediate Reserve (EWR) sites (DWAF, 2008b). Google images and historic information on the catchment were also taken into consideration when sites were selected. The chosen sites were then groundtruthed during field sampling by a team of specialists in April 2010 and the final location verified. Unseasonal floods during the fieldwork hampered the data collection. As the Mokolo River is semipermanent it was possible for most specialists to use the methods designed for perennial rivers for data collection. If the river was ephemeral or episodic, adjusted sampling and interpretation methods would be needed. At present, no formal method has been developed for the collection of data on non-perennial rivers in the different disciplines.

- Indicators: Indicators were chosen specifically for nonperennial rivers and these can be adjusted according to the type of river studied. A summary of indicators and links is presented in Table 3.

\section{Phase 6: Complete specialist studies}

Specialist studies were completed where a multidisciplinary team sampled the Mokolo River in April 2010.

- Geomorphology: Due to the high flood levels during the time of sampling, Google Earth images were used to produce an initial geomorphological sketch map to indicate the location of channel banks, benches and flood zones within a 100-200 m length of channel. A final channel morphology map was produced after comparing the surveyed transects to the features shown on the satellite images. A channel cross-section was surveyed using levelling and water depth measurements across transects to estimate the channel bed topography. In non-perennial rivers, with characteristically high sediment loads, sediment becomes a key driving variable, influencing rooting depth and water availability in the riparian zone. Sediment samples were collected from each exposed morphological feature, including channel bed, banks, and the three flood zones. Particle size analysis was done using sieves to fractionate the sediment into coarse $(2-0.5 \mathrm{~mm})$, medium $(0.5-0.25 \mathrm{~mm})$ and fine sand $(0.25-0.063 \mathrm{~mm})$, and silt and clay $(0-0.063 \mathrm{~mm})$. Sediment size was described using the $\mathrm{d} 84, \mathrm{~d} 50$ and $\mathrm{d} 16$ particle sizes.

- Water quality: The water temperature $\left({ }^{\circ} \mathrm{C}\right)$, conductivity $(\mu \mathrm{S} / \mathrm{cm})$ and total dissolved salts (ppt or $\mathrm{g} / \mathrm{L})$, concentration of dissolved oxygen $(\mathrm{mg} / \mathrm{L})$ and percentage of saturation $\left(\mathrm{O}_{2} \%\right)$ were measured, in situ from the shore, with an YSI Model 85 meter. $\mathrm{pH}$ and redox measurements were taken in situ using a Euteck Instrument CyberScan pH 110 meter. A number of subsurface water samples were collected and then transported in a portable ice chest to the laboratory. Diatom samples were collected according to the method described in Taylor et al. (2007) and preserved with $90 \%$ alcohol.

- Riparian vegetation was surveyed using the VEGRAI (Riparian Vegetation Response Assessment Index) method as described by Kleynhans et al. (2007)

- Macroinvertebrates were sampled using the standard South African Scoring System (SASS5) method (Dickens and Graham, 2002) and the Okavango Assessment System (OKASS) method (Dallas, 2009).

- Fish: Flooding during sampling necessitated that fish samples were taken in the lateral flooded areas, which were more accessible than the fast-flowing main channel. A combination of electro-narcosis, seine net and fyke net sampling was done depending on the habitat type and conditions to be sampled.

- Socio-economics: The socio-economic analysis identified the stakeholder groups that interact with the Mokolo River and included stakeholders from the commercial agricultural sector, the mining and power generation sectors, individual users and development agencies working in the area. A purposive sampling method was employed by selecting key stakeholders from the community to provide information on people-ecosystem interactions relating to the Mokolo River. 


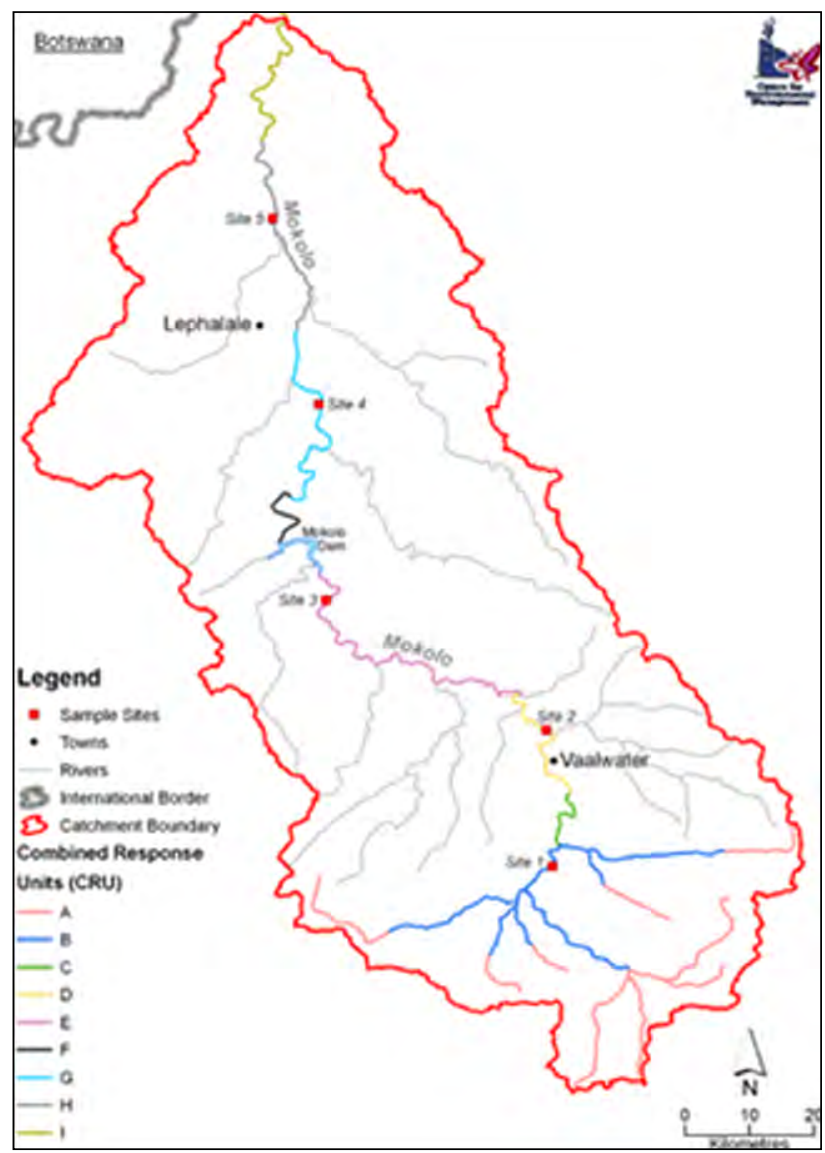

Figure 6

Map indicating the Mokolo River Combined Resource Units (CRUs) and sites chosen

\section{Phase 7: Choose scenarios and complete hydrological simulation of scenarios}

Possible development scenarios were chosen by the team, using socio-economic, historic and recent data on the Mokolo River catchment. The hydrological simulation to produce a daily time series for the scenarios chosen was completed using the MIKESHE integrated groundwater and surface water model (Prucha and Graham (2012) and Prucha et al. (2016)). The daily time series of data provided by the model included data on the river discharge, river stage, depth to groundwater beneath river, baseflow to river and subsurface flow beneath river.

The demand for water in the Mokolo River, the most economically developed catchment in the Limpopo Water Management Area, is increasing, and, concomitantly, the interactions between the ecological and social systems could increase in scale and complexity. The social environment is not site-specific. At Sites 1-3, the population is mainly rural and engaged in commercial crop farming and game farming. At Sites 4-5 mining and power generation are additional factors. The population at Sites 4-5 is, largely, still agricultural, with the exception of the town of Lephalale that is characterised by extensive urban development resulting from the expansion of the mine and the building of the Medupi Power Station. Recently, many farms have been converted from crop-producing farms to game farms. There is definite potential for tourism development in the area, but this is partly reliant on the preservation of the ecosystem surrounding the river.
Hydrological simulations for all scenarios consisted of 50 years of data, based on the initial modelling for the present day, using 8 gauging stations (Fig. 2) which had overlapping observed data. All flow upstream of the Mokolo Dam was routed downstream to the outlet of the Mokolo River (through Gauge A4H014). Detailed climate data were also available for the Mokolo Catchment from 1950-2000 (Schultz and Maharaj, 2007). The five scenarios chosen were:

- Scenario 1: Present day (PD): The 50-year simulations included the main infrastructure present at the time of the study (Mokolo Dam, and 31 other structures including 25 dams, and 6 weirs), i.e., the whole time series represents what would happen if the same climatic conditions of the previous 50 years were repeated for another 50 years with current (2010) levels of infrastructure.

- Scenario 2: Natural/reference: The 50-year PD simulations were modified by (a) estimating a natural stream profile through the Mokolo Dam based on the upstream and downstream profile, and (b) excluding farm dams, irrigation, interbasin transfers and weirs.

- Scenario 3: Game farming (GameFarm): The 50-year PD simulations were modified by (a) changing the vegetation, upstream of Mokolo Dam, from irrigated agriculture to natural, and (b) keeping development downstream of the Mokolo Dam the same as PD.

- Scenario 4: External water (ExtWater): The 50-year PD simulations were modified by (a) adding an interbasin transfer from the Crocodile River to the Mokolo Basin, and (b) keeping development upstream of the Mokolo Dam the same as PD. The interbasin transfer was made to support expansion of the Exxaro mine, Eskom power plants (Medupi and Matimba) and Lephalale town water supply. Water was applied in these scenarios using the irrigation module as if the water would be used for irrigation and no water was released back into the Mokolo River after use. No vegetation change was made from the PD vegetation.

- Scenario 5: Combined: The 50-year PD simulations were modified by (a) adding the interbasin transfer of Scenario 4, and (b) changing land-use from irrigation to game farming as for Scenario 3. Therefore, Scenario 5 is a combination of Scenarios 3 and 4 .

The hydrological simulation to produce a daily time series for the five scenarios was completed. Only the surface flow results from the hydrological simulation for Site 4 (below the dam) will be presented here (for full results, see Prucha and Graham, 2012 and Prucha et al., 2016).

At Site 4, there is little difference between the PD and ExtWater scenarios. The water transferred from the Crocodile River was not modelled to reach the Mokolo River, either due to releases from the dam, or due to return flows from mining or agriculture. However, the ExtWater scenario does improve water availability for irrigation, mining and power production. There is little difference between the Natural, GameFarm and Combined scenarios. This is because, in the GameFarm and Combined scenarios the change from irrigation to game farming above the dam was modelled to produce much higher releases from the dam than currently takes place, and the change to game farming dominates flows in the resulting Combined scenario. The resulting flows are similar to Natural flows (Fig. 7). 


\section{Phase 8: Knowledge capture}

The DRIFT-ARID DSS was populated with the 5 site names, 17 flow indicators, 5 hydraulic indicators, 5 scenario indicators (e.g. hectares of irrigation) (see Table 3 ), 5 scenario names, and other information such as the start year of the hydrology (1950). A screen shot of part of the 'Setup' page is shown in Fig. 8.

A file was set up for each specialist area for each site, including hydrology. The hydrology site files also house the hydraulics and scenario indicators which were managed in the same way as the flow indicators. Each site-level hydrology file (e.g. Hydro_Site 4_BeDam.xlsb for Site 4 'below dam') contains the time series of flow indicators for each scenario. Figure 9 shows an example of the time series of flow indicators entered for Site 4 for the Present Day (PD) scenario.

Each specialist data entry file was pre-populated with the flow indicators, the discipline's indicators, and standard information such as site and scenario names. Figure 10 shows an example of the specialist's indicator list for fish. These can be deactivated if they are irrelevant for a particular site.
The specialist had to specify flow and other indicators linked to each of his/her indicators (see Table 3). A macro was used to prepare data entry sheets with blank response curves for each linked indicator. Part of the sheet for entering links is shown in Fig. 11.

Response curves were then completed on the page prepared for each of the specialists' indicators. Three of the response curves are shown in Fig. 12, dealing with the 'shallow pool dwelling species' response to (a) the duration of inundation of flood zone 2 (FZ2), (b) the duration of time with no surface flow, and (c) the average depth in the dry season. The values in the yellow-shaded cells ('min') were completed by the specialist in response to the values to the right ('days'). The values in the 'days' column are a range of values for that input indicator, including the median PD value, the $\mathrm{PD}$ range, and an extended range to accommodate scenarios. The DSS also allows for a range of response values ('min' and 'max') to allow for greater uncertainty than that already implied by the response scores. The range is shown in the response curve graphs as paler blue lines (Fig. 12). See Seaman et al. (2013) for details of the scoring system used.

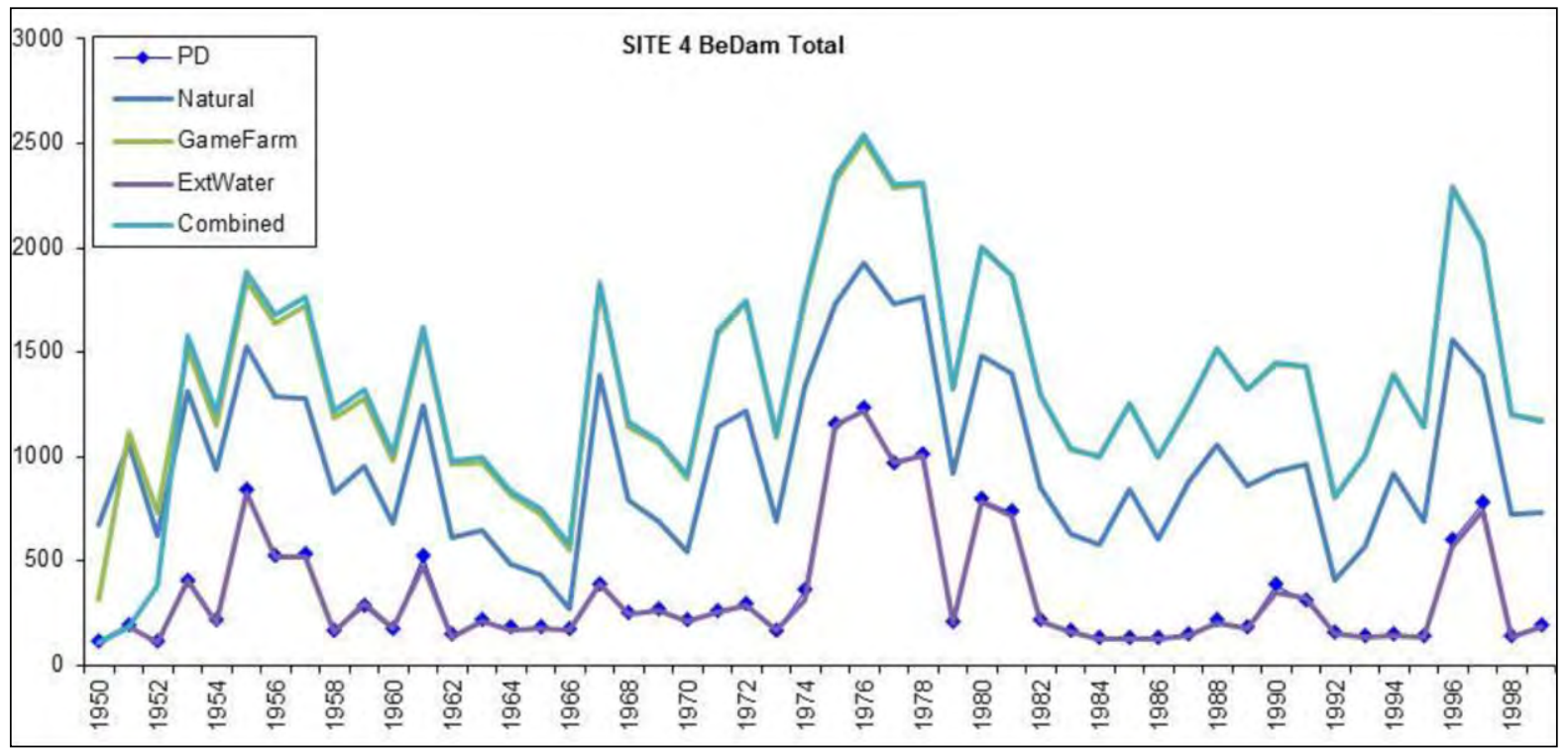

Figure 7

Total annual volume of surface flow (MAR) at Site 4 on the Mokolo River from 1950-2000

\begin{tabular}{|c|c|c|c|c|c|c|c|c|c|c|c|}
\hline \multicolumn{4}{|c|}{ 3.) SCENARIO NAMES } & \multicolumn{3}{|c|}{ 4.) SPECIALIST AREAS } & \multicolumn{5}{|c|}{ 5.) SITE / REACH NAMES } \\
\hline & & $\begin{array}{c}\text { CHANGE } \\
\text { HERE }\end{array}$ & & & $\begin{array}{c}\text { CHANGE } \\
\text { HERE }\end{array}$ & Complete list & & $\begin{array}{c}\text { CHANGE } \\
\text { HERE }\end{array}$ & $\begin{array}{l}\text { CHANGE } \\
\text { HERE }\end{array}$ & & $\begin{array}{l}\text { CHANGE } \\
\text { HERE }\end{array}$ \\
\hline & 1 & PD & PD & Hydro & Hydro & Hydro & 1 & Site 1 & TweeF & TweeF & River \\
\hline & 2 & Natural & Natur & Geomo & Geomorph & Hydraulics & 2 & Site 2 & VaalW & VaalW & River \\
\hline & 3 & Game & Game & Water & Water quality & Sediment & 3 & Site 3 & Ab_Dam & Ab_Da & River \\
\hline & 4 & ExtWater & ExtWa & Veget & Vegetation & Geomorph & 4 & Site 4 & Bel_Dam & Bel_D & River \\
\hline & 5 & Combo & Combo & Macro & Macroinverts & Water Quality & 5 & Site 5 & Bel_Sand & Bel_S & River \\
\hline & 6 & Blank6 & Blank & Fish & Fish & Vegetation & 6 & & Blank & Blank & Floodplain \\
\hline & 7 & Blank7 & Blank & Socio & SocioEcon & Macroinverts & 7 & & Blank & Blank & River \\
\hline & & Blank8 & Blank & Blank & Blank & Fish & 8 & & Blank & Blank & $\mathbf{0}$ \\
\hline & & Blank9 & Blank & Blank & Blank & Mammals & 9 & & Blank & Blank & \\
\hline & & Blank10 & Blank & Blank & Blank & SocioEcon & 10 & & Blank & Blank & \\
\hline & & Blank11 & Blank & Templ & Template & Template & 11 & & Blank & Blank & \\
\hline
\end{tabular}

Figure 8

Part of the 'Setup' page of the Scenario Interface file for the Mokolo River, showing scenarios, disciplines and site names 


\begin{tabular}{|c|c|c|c|c|c|c|c|c|c|c|c|c|c|c|c|c|c|c|c|c|c|c|}
\hline \multirow{3}{*}{$\begin{array}{l}\text { ALL STATIS } \\
\text { Year }\end{array}$} & $\begin{array}{r}\text { H1 } \\
\text { STICS PD }\end{array}$ & H2a & $\mathrm{H} 2 \mathrm{~b}$ & H4a & H4b & H5 & $\mathrm{H} 6$ & H7 & H8 & $\begin{array}{l}\text { H9 } \\
188^{\prime}\end{array}$ &,$\quad \mathrm{H} 10$ & H11 & $\begin{array}{r}\mathrm{H} 12 \\
\quad 36\end{array}$ & H13 & H14 & H15 & H16 & Hуз & Hy 4 & Hy 5 & Hy6 & $\mathrm{Hy} 7$ \\
\hline & MAR & DDepCh & WDepd & DDGr & WGr & WoDry & WoWet & WFZ1 & WFZ2 & WIndFZ2 & WFZ3 & W13 & WPk & Wdur & Do & $\mathrm{Dd}$ & Dsub & FloodH & FlowLT & FlowGT & Ddep & Wdep \\
\hline & \begin{tabular}{|l|}
$\begin{array}{l}\text { Total annual } \\
\text { volume of } \\
\text { surface flow } \\
\text { (MAR) }\end{array}$ \\
\end{tabular} & \begin{tabular}{|l} 
Depth \\
of \\
water \\
table, \\
chann \\
el, dry
\end{tabular} & 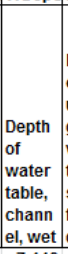 & \begin{tabular}{|l|} 
Perc \\
contrib \\
ution of \\
ground \\
water \\
to \\
surface \\
flow, \\
dry \\
\end{tabular} & \begin{tabular}{|l} 
Perc \\
contrib \\
ution of \\
ground \\
water \\
to \\
surface \\
flow, \\
wet \\
\end{tabular} & \begin{tabular}{|l} 
Onset \\
of \\
surfac \\
e flow \\
after \\
period \\
of dry \\
river \\
bed \\
\end{tabular} & $\begin{array}{l}\text { Onset } \\
\text { of } \\
\text { hydro } \\
\text { wet } \\
\text { seaso } \\
\text { nafter } \\
\text { a } \\
\text { period } \\
\text { of wet } \\
\text { river } \\
\text { bed } \\
\end{array}$ & $\begin{array}{l}\text { No of } \\
\text { floods } \\
\text { per } \\
\text { year } \\
\text { that } \\
\text { cover } \\
\text { FZ1 } \\
\end{array}$ & \begin{tabular}{|l} 
No of \\
floods \\
per \\
year \\
that \\
cover \\
FZ2 \\
\end{tabular} & $\mid \begin{array}{l}\text { Longest } \\
\text { duration } \\
\text { of } \\
\text { inundati } \\
\text { on of } \\
\text { FZ2 }\end{array}$ & \begin{tabular}{|l|} 
No of \\
floods \\
per \\
year \\
that \\
enter \\
FZ3 \\
\end{tabular} & \begin{tabular}{|l} 
Flood \\
greater \\
than PD \\
1.3 \\
magnitu \\
de
\end{tabular} & \begin{tabular}{|l}
$\begin{array}{l}\text { Peak } \\
\text { flow } \\
\text { discha } \\
\text { rge }\end{array}$ \\
\end{tabular} & $\begin{array}{l}\text { Surface } \\
\text { flow } \\
\text { duration }\end{array}$ & $\begin{array}{l}\text { No } \\
\text { surfac } \\
\text { eflow } \\
\text { onset }\end{array}$ & \begin{tabular}{|l} 
No \\
surface \\
flow \\
duration
\end{tabular} \mid & $\begin{array}{l}\text { Channel } \\
\text { subsurfac } \\
\text { e flow, dry }\end{array}$ & $\begin{array}{l}\text { Height of } \\
\text { max flood } \\
\text { per year }\end{array}$ & \begin{tabular}{|l|} 
Length \\
flow LT \\
0.3
\end{tabular} & \begin{tabular}{|l|} 
Length \\
flow \\
GT 0.3 \\
\end{tabular} & \begin{tabular}{|l} 
Average \\
depth \\
dry \\
season
\end{tabular} & \begin{tabular}{|l} 
Average \\
depth \\
wet \\
season \\
\end{tabular} \\
\hline 1950 & 109.686 & -7.449 & -7.448 & 11.532 & 2.3113 & -55 & 55 & & 1 & 1 & 1 & & $\begin{array}{ll}0 \quad 2.018 \\
\end{array}$ & 309 & 55 & 25 & 0.000545 & 2.675543 & 215 & 94 & 1.6268 & 1.8347 \\
\hline 1951 & 188.936 & -7.446 & -7.447 & 3.0744 & $\quad 2.0302$ & -55 & 55 & & 0 & 0 & 0 & & $\begin{array}{ll}0 & 3.507\end{array}$ & 365 & 55 & 0 & 0.000551 & 3.268887 & 188 & 177 & 1.819 & 1.91548 \\
\hline 1952 & 105.677 & -7.446 & -7.449 & 3.2712 & 2.8454 & 28 & 55 & & 0 & 0 & 0 & & $\begin{array}{ll}0 & 1.859\end{array}$ & 10 & 26 & 55 & 0.000566 & 2.604122 & 168 & 142 & 1.7703 & 1.75066 \\
\hline 1953 & 398.457 & -7.448 & -7.444 & 4.3291 & 1.0123 & -55 & 24 & & 2 & 0 & 0 & & $\begin{array}{ll}0 & 5.289\end{array}$ & 34 & 55 & 1 & 0.000573 & 3.856737 & 76 & 288 & 1.7125 & 2.35465 \\
\hline 1954 & 210.011 & -7.447 & -7.447 & 3.3563 & 1.5716 & 25 & 55 & & 0 & 0 & 0 & & 3.78 & 339 & 24 & 26 & 0.000573 & 3.365031 & 103 & 236 & 1.7599 & 1.9763 \\
\hline 1955 & 833.477 & -7.447 & -7.445 & 2.1611 & 0.47 & -55 & 10 & & 6 & $\begin{array}{ll}3 & 39.333\end{array}$ & 1 & & 112.45 & 35 & 55 & 0 & 0.000549 & 5.348339 & 48 & 317 & 1.8606 & 2.92165 \\
\hline 1956 & 520.091 & -7.446 & -7.446 & 4.7758 & 0.6438 & -55 & 17 & & 5 & 34 & 0 & & 5.7 & & & 5 & 0.000541 & 3.980351 & 63 & 297 & 1.7421 & 2.52249 \\
\hline 1957 & 526.319 & -7.449 & -7.447 & 2.176 & 0.6238 & -55 & 17 & & & 20 & 1 & & 18.269 & 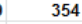 & 55 & 11 & 0.000558 & 4.64 & 59 & 295 & 1.7828 & 213 \\
\hline 1958 & 161.569 & -7.446 & -7.446 & 5.1884 & $\begin{array}{l}2.1253 \\
+\end{array}$ & 26 & 55 & & 0 & 0 & 0 & & $\begin{array}{ll}0 & 3.069\end{array}$ & 9 & 24 & 31 & 0.000581 & 3.104069 & 170 & 164 & 1.7294 & 1.88069 \\
\hline 1959 & 280.556 & -7.448 & -7.445 & 4.3954 & $\begin{array}{r}+ \\
+\end{array}$ & -3 & 55 & & 0 & 0 & 0 & & 15.656 & & & 14 & 0.000551 & 3.966616 & 83 & 268 & 1.6967 & 2.13747 \\
\hline 1960 & 172.338 & -7.445 & -7.447 & 2.4165 & $\begin{array}{l}5.2369 \\
\end{array}$ & -55 & 55 & & & 0 & 0 & & $\begin{array}{ll}0 & 4.521\end{array}$ & 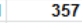 & 55 & 8 & 553 & 004 & 196 & 61 & 1.8434 & 1.86328 \\
\hline 1961 & 515.111 & -7.448 & -7.443 & 2.891 & 0.8551 & -55 & 11 & & 6 & $\begin{array}{ll}3 & 21.333\end{array}$ & 0 & & 16.056 & i & 55 & 0 & 537 & 4.08 & 76 & 89 & 1.7745 & 2.5213 \\
\hline 1962 & 141.505 & -7.448 & -7.448 & 4.4865 & 2.1178 & -55 & 55 & & 0 & 0 & 0 & & $\begin{array}{ll}0 & 2.236\end{array}$ & j & 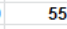 & 6 & & 394 & 209 & 150 & 1.7061 & 1.85421 \\
\hline 1963 & 212.308 & -7.444 & -7.446 & 2.8543 & $\begin{array}{l}3.937 \\
\end{array}$ & -55 & 19 & & & 0 & 0 & & $\begin{array}{ll}0 & 4.828\end{array}$ & 55 & 5 & 0 & 0.000553 & 3.713895 & 188 & 177 & 1.8341 & 1.95195 \\
\hline 1964 & 174.808 & -7.447 & -7.447 & 2.745 & 52 & 27 & 55 & & 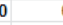 & 0 & 0 & & $\begin{array}{ll}0 & 4.179\end{array}$ & 9 & 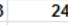 & 42 & 0.000554 & 379 & 134 & 89 & 1.8262 & 1.87286 \\
\hline 1965 & 174.586 & -7.448 & -7.446 & 5.8619 & 1.9192 & -55 & 9 & & 0 & 0 & 0 & & \begin{tabular}{l|l}
1 & 6.518
\end{tabular} & 350 & 55 & 15 & 559 & & 187 & 163 & 1.6772 & 1.92185 \\
\hline 1966 & 166.554 & -7.448 & -7.447 & 4.4325 & 2.0016 & 28 & 9 & & 2 & 12 & 0 & & $\begin{array}{ll}0 & 4.103\end{array}$ & 99 & 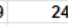 & 36 & 549 & 656 & 179 & 50 & 1.7089 & 1.89082 \\
\hline 1967 & 377.669 & -7.445 & -7.441 & 2.9262 & 1. & -55 & & & 6 & $\begin{array}{ll}3 & 9.3333\end{array}$ & & & 1 & & & 0 & 0.000493 & 063 & 48 & 17 & 1.8113 & 2.25129 \\
\hline 1968 & 242.253 & -7.448 & -7.444 & 3.6027 & 1.713 & -55 & 20 & & 5 & 10 & 0 & & 5.31 & 1 & 5 & 5 & 0.000534 & 3.862231 & 96 & 70 & 1.7487 & 2.04118 \\
\hline 1969 & 262.802 & -7.447 & -7.444 & 2.722 & 1.637 & -55 & 15 & & & 11 & 0 & & 15.897 & & 55 & 0 & 554 & 4.038037 & 133 & 32 & 1.823 & 05358 \\
\hline 1970 & 275 & -7.446 & -7.446 & 3.4821 & 1.8 & -50 & 50 & & 0 & 0 & & & 0 & & 55 & 2 & 0.000582 & & 126 & 237 & 1.8023 & 1.96397 \\
\hline 1971 & 254.682 & -7.445 & -7.446 & 2.5516 & 1) 1.697 & -55 & 2 & & 3 & 13 & 0 & & $\begin{array}{ll}0 & 4.891 \\
\end{array}$ & 365 & 55 & 0 & 0.000549 & 3.733124 & 135 & 230 & 1.9195 & 2.00702 \\
\hline
\end{tabular}

Figure 9

Screenshot of the PD flow, hydraulic and scenario indicators entered into the hydrology file for Site 4 of the Mokolo River

\begin{tabular}{|c|c|c|c|c|c|}
\hline & IIST OF INDICATORS FOR: & & Indicators are picked & enario Interface" & \\
\hline & BEDAM & SITE 4 & Switch on / off the inc & (0 where blank), & Column F \\
\hline & Figh & & State relationship be & lance and integrit & ty, Column G \\
\hline & & & Fill in Discipline PES & Disapline PES: & $\mathrm{c}$ \\
\hline $\begin{array}{l}\text { Num } \\
\text { Char }\end{array}$ & Indiators / P rocess[sub)-indicato rs & $\begin{array}{l}\text { Indicators [if process indicators } \\
\text { present, else EMPTY) }\end{array}$ & & & \\
\hline 21 & 1 Rapid, riffle dwelling & 0 & Description & $\begin{array}{l}\text { Switch indiators } \\
\text { ON (1) or OFF (0) }\end{array}$ & $\begin{array}{c}\text { Is an INCREASE a move } \\
\text { towards (T) or away (A) } \\
\text { from natural? }\end{array}$ \\
\hline 18 & 2 Deep pool dwelling & 0 & 0 & 1 & $\mathrm{~T}$ \\
\hline 21 & 3 Shallow pool dwelling & 0 & 0 & 1 & $T$ \\
\hline 7 & $4 \longdiv { \text { Blank } 4 }$ & 0 & 0 & 1 & $\mathrm{~T}$ \\
\hline
\end{tabular}

Figure 10

Specialist data entry file, showing the list of indicators and where they can be deactivated for a particular site

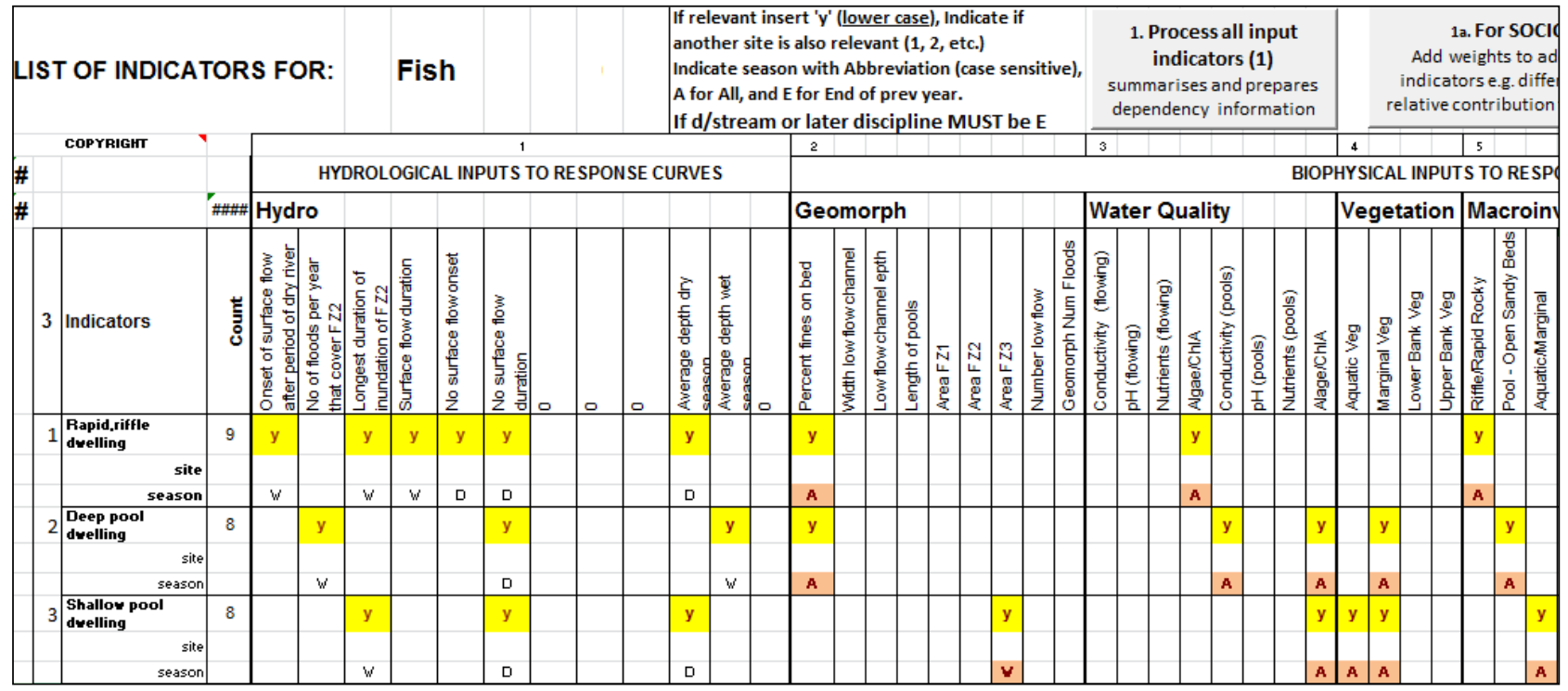

Figure 11

Specialist data entry file, where linked indicators are specified 


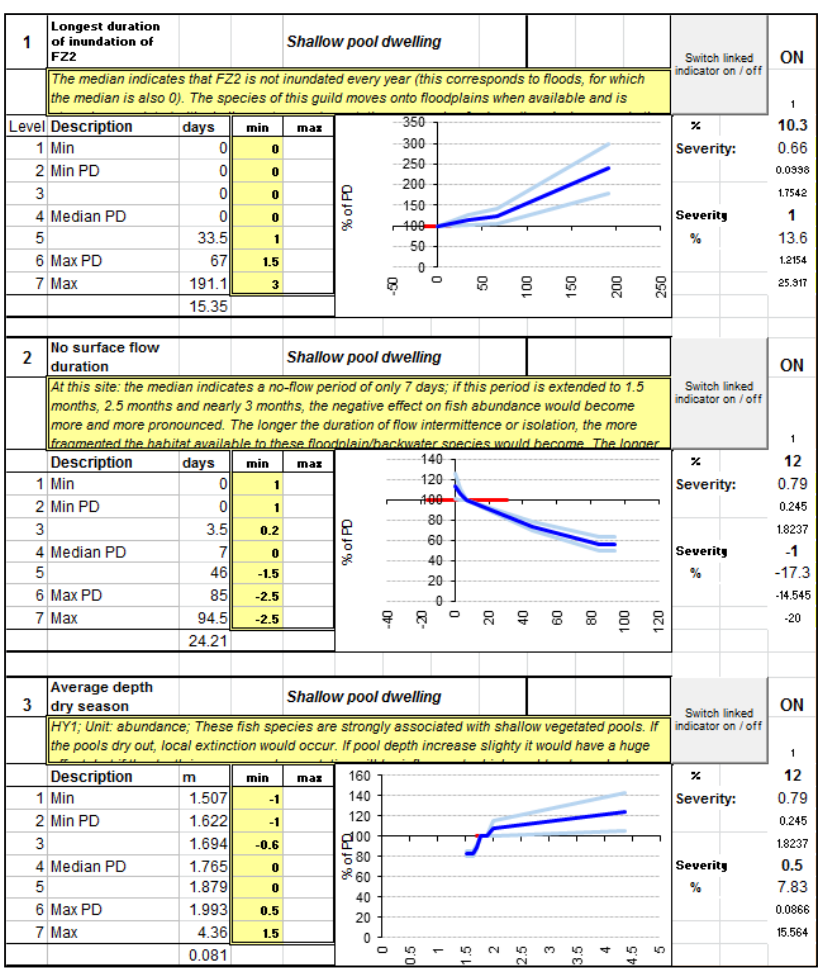

Figure 12

Response curves for 'Fish' indicator: Shallow pool-dwelling species, for the first three linked indicators (1) the duration of inundation of Flood Zone 2 (FZ2), (2) the duration of time with no surface flow, and (3) the average depth in the dry season

\section{Phase 9: Scenario analysis}

Figure 13 shows an aggregate seasonal response time series on the top of each indicator's page and, to the right of the response time series, various modifications that can be made to the responses to adjust the overall time series response.

Each specialist file includes various other summaries, as well as an annual response time series (Fig. 14) as opposed to the seasonal one (Fig. 13).
The PD scenario response for each indicator was calibrated by adjusting the response curves, so that the median of the PD scenario's overall response ranged between $95 \%$ and $105 \%$ of the PD (see value indicated under average of scenario (93.77\%) in Fig. 13. Hydrology data from three calibration scenarios (all wet, all dry and wet and dry, see Seaman et al. 2013; 2016) were also included in the DSS and the specialists further calibrated the response curves and modifiers while viewing results of these extreme scenarios (which test the outer ranges of the response curves). For example, it would be expected that the abundance of riffle-rapid dwelling fish species would increase continuously up to a certain maximum in the 'wet' scenario and decrease drastically in the 'dry' scenario.

The DRIFT-ARID DSS was then run and the output presented to the specialists for verification.

\section{OUTCOMES OF METHOD}

\section{Phases 10 and 11: Evaluate scenarios and provide outputs}

As an example of DRIFT-ARID output, only scenario results for Site 4 and for geomorphological change are presented here. For details on other specialist field results, please refer to Seaman et al. (2013).

The outcome of running the five scenarios is illustrated in Figs $15 \mathrm{a}-\mathrm{j}$ and Fig. 16. In all scenarios, the low-flow channel width (b), low-flow channel depth (c), geomorphic pool depth (d) and pool length (e) responded synchronously in response to increased or decreased flood events. The feedback between low-flow channel depth and the number of floods inundating Flood Zone 1 (FZ1) can be seen in (j). FZ1, as expected, was the most responsive to changes in channel width (f), with a varied response between scenarios. The extent of the other flood zones varied little for all scenarios through time.

Figure 16 shows the summary results of geomorphological health or integrity at Site 4 for the five scenarios. The site was in a B/C (good to fair) category in the PD scenario and improved to an A/B (natural to largely natural) category for the GameFarm and Natural scenarios. The ExtWater scenario had the largest negative impact (loss in pool depth and low-flow channel width with a concomitant gain in FZ1). It is uncertain

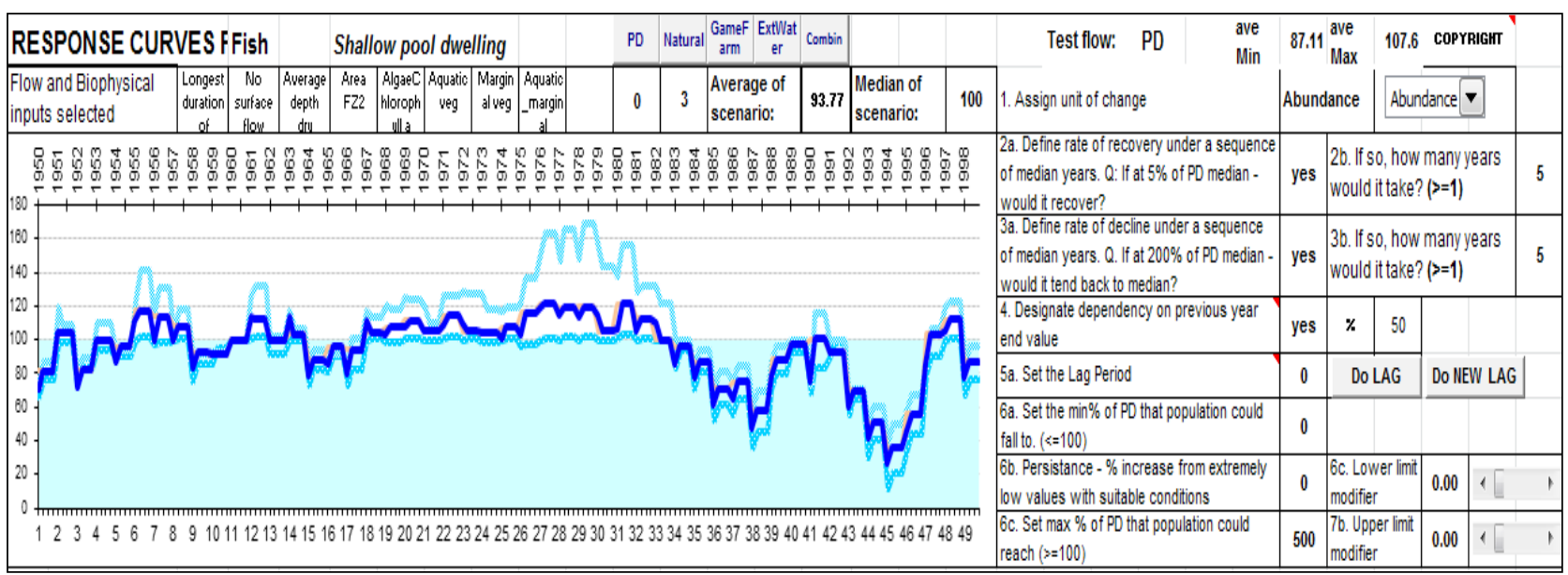

Figure 13

Screenshot of the seasonal time series response built up from the responses to a time series of eight input indicators for Site 4 of the Mokolo River. To the right (grey and blue blocks) are various modifications that can be made, e.g., inclusion of lag periods 


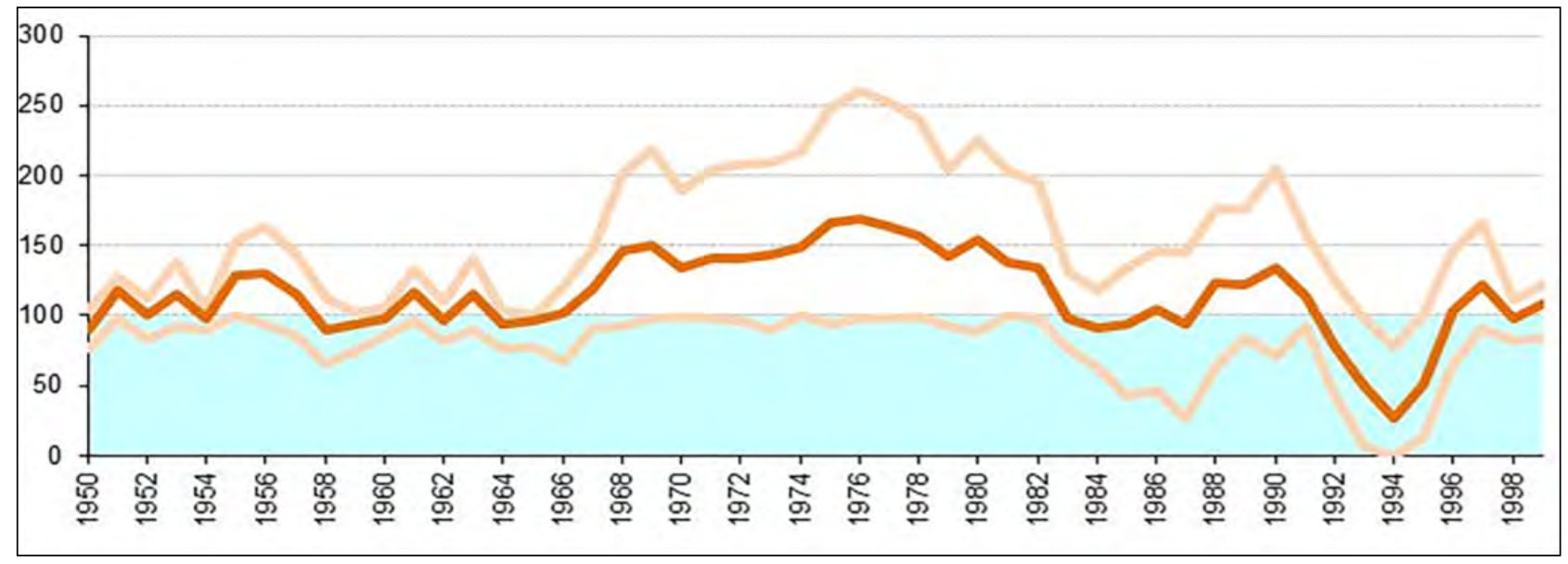

Figure 14

Annual time series resulting from the seasonal time series in Figure 13 ( $Y$ axis = percentage of present day)

why these changes would have resulted from this scenario, unless there was a reduction in floods at the expense of increased baseflow. However, the responses in geomorphology at Site 4 are all very small.

The DRIFT-ARID DSS uses the integrity scores from each of the disciplines to determine the overall ecosystem integrity of the site under the different scenarios (Fig. 17). It is worth noting that, given the problems with hydrological modelling (inconsistency with data etc., see Prucha et al., 2016) and scenario definition, these are hypothetical results only, and no conclusions should be drawn from them regarding the actual performance of the different scenarios. An increase in integrity is noted in all scenarios except in ExtWater where integrity is negatively impacted (dropping a category from overall B to overall C, bordering D (Fig. 17).

\section{DISCUSSION}

The research in the current EWR projects (Rossouw et al., 2005; Seaman et al., 2010; 2013) has contributed considerably to the knowledge on the ecological functioning of non-perennial rivers in South Africa, and the testing of DRIFT-ARID. DRIFT is one of the DWS-approved methods for determining the EWRs of South African rivers and has been used in many national and international rivers (e.g. Olifants-Doorn - Brown et al. (2006); Zambezi Basin - Beilfuss and Brown (2006); Lesotho rivers - King et al. (2003), and the Mekong River - MRC (2006)). DRIFT-ARID, however, has only been tested on the semi-permanent Mokolo River (Seaman et al., 2013).

Some of the requirements for an effective EWR method as discussed by Cottingham et al. (2002) are included in the DRIFT-ARID method, including guidelines on site selection and collection of data, the consideration of social and economic implications, and a standardised process for the presentation and documentation of outcomes.

Determining the degree of perenniality is vital as each type of non-perennial river needs to be approached differently (Seaman et al., 2010; 2013). For semi-permanent rivers (Mokolo River) both the perennial and non-perennial EWR methods could be used, but for ephemeral rivers (Seekoei and Fish Rivers) perennial methods are less useful (Seaman et al., 2010; Palmer, 2013). In the Mokolo River study, soil scientists contributed valuable data for integrated groundwater-surface water modelling. In episodic rivers, macroinvertebrate and fish specialists would be less vital than in perennial rivers, whereas vegetation, mammal (wildlife) and terrestrial insect specialists would become more important (Seaman et al., 2013). A hydraulic specialist should be included in all studies although the traditional hydraulic approach used in EWR studies would have to be adjusted in non-perennial rivers. Hydraulic input for crosssections of pools and riffles is crucial for accurate integrated groundwater-surface water modelling. In non-perennial systems pool depth and volume become important indicators (Prucha and Graham, 2012; Seaman et al., 2013), whereas riffles are more important in perennial systems.

The catchment delineation process is a standard approach in EWR assessments and in the Water Resource Classification System in South Africa (WRCS; Dollar et al., 2007). The DRIFTARID method augments the standard approach with the addition of RPUs to supplement the lack of gauging weir data in data-scarce regions.

The site selection method is also similar to the approaches followed for perennial rivers (e.g. Louw et al., 1999) and in the Water Resource Classification System (Dollar et al., 2007). The determination of CRUs and their importance ranking in the DRIFT-ARID method requires input from all specialists involved in the study and could be compared to the importance ranking used in DWA (2010). Studies comparing the two methods are needed to verify the preferred method.

The project used an integrated groundwater and surface water hydrology model, MIKE-SHE (Graham and Butts, 2005), for the whole catchment. Hydrology is one of the main drivers of the DRIFT-ARID method and the importance of groundwater in non-perennial rivers was emphasised in the previous EWR projects (Rossouw et al., 2005; and Seaman et al., 2010). One of the main constraints in one previous EWR project (Seaman et al., 2010) was the difficulty in modelling the hydrology of non-perennial rivers (specifically the ephemeral Seekoei River) due to a shortage in gauging-weir data and the absence of a suitable hydrological model for integrated surface and groundwater modelling (Hughes, 2008). The use, in this project, of MIKE-SHE for an entire catchment was a first for non-perennial rivers in South Africa. However, an integrated method, a simple classification scheme based on the geological setting of selected river stretches and the prevailing hydraulic gradients between surface and groundwater as proposed by Witthüser in DWA (2010a), was used to model a section of the Mokolo River in the Intermediate Reserve study. For challenges identified in applying the MIKE-SHE model see Prucha and Graham (2012) and Prucha et al. (2016). 


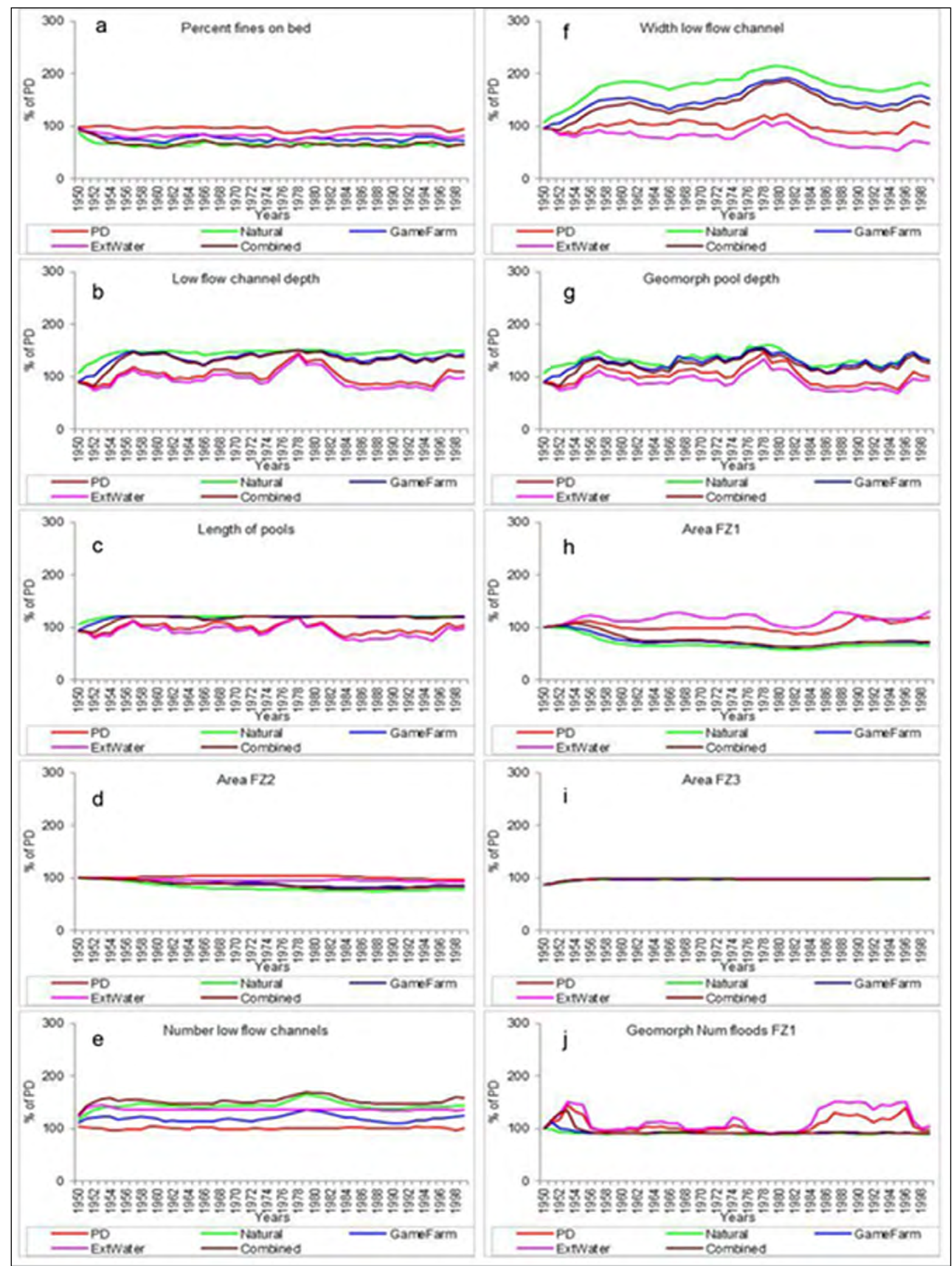

Figure 15

Geomorphology output for the 5 scenarios for 10 indicators at Site 4 


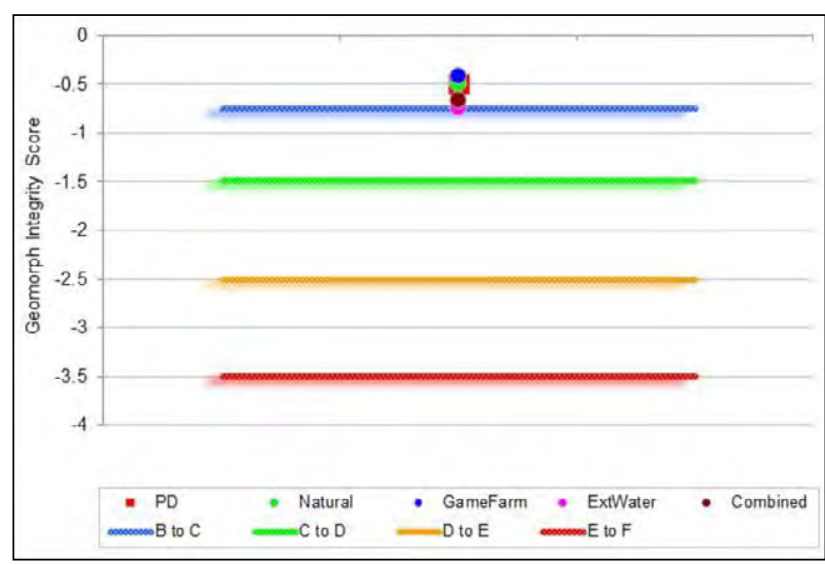

Figure 16

Integrity scores for geomorphology at Site 4

The likely future scenarios included in the study had some limitations, particularly as all implied an increase in flow relative to current flow. At least one scenario should have been included which had more water being abstracted from the river or groundwater.

Scenario results using the DRIFT-ARID DSS provided an ecological integrity score for each site and each scenario. It is difficult to compare results from all scenarios in the present study with other studies on the Mokolo River as the scenarios differed in assumptions made. Results from the PD scenario compared to results from DWAF (2008a, using ECOSTATUS) indicated that Site EWR4 (DWAF, 2008a), which was downstream of Site 4 (present study), was in a C (moderately modified) category, compared to the B category (largely natural; Fig. 16) obtained in this study using the DRIFT-ARID method. It is not possible to assess which of these is correct in terms of integrity and this anomaly emphasises the importance of developing and testing methods for EWR determinations in all rivers as the management of the rivers is reliant on accurate results.

\section{CONCLUSIONS AND RECOMMENDATIONS}

A EWR method for non-perennial rivers, namely DRIFT-ARID, has been developed. Several adaptations to the original DRIFT method had to be made to accommodate non-perennial river characteristics.

Some additional findings and recommendations from the current study are the following:

In each of the disciplines, specific constraints and challenges were identified when using the current perennial methods to determine the Present Ecological State (PES). Studies are needed in non-perennial rivers in order to determine links between flow and habitat availability, especially to determine what the critical stage in habitat and flow change is before generalist species (usually found in non-perennial rivers) are affected.

Generic indicators for non-perennial rivers need to be identified, and for this more long-term data on non-perennial rivers is needed. Event hydrology, groundwater-surface water interactions, sediment transport processes and vegetation all drive channel dynamics in non-perennial systems. Fish may not be present in episodic rivers, and fish and macroinvertebrates may not be observed during no-flow conditions. However, channel morphology showed the integrated response to past flows, and deep-rooted vegetation will be sustained through dry periods (Rowntree and Van der Waal, 2012). Indicators for

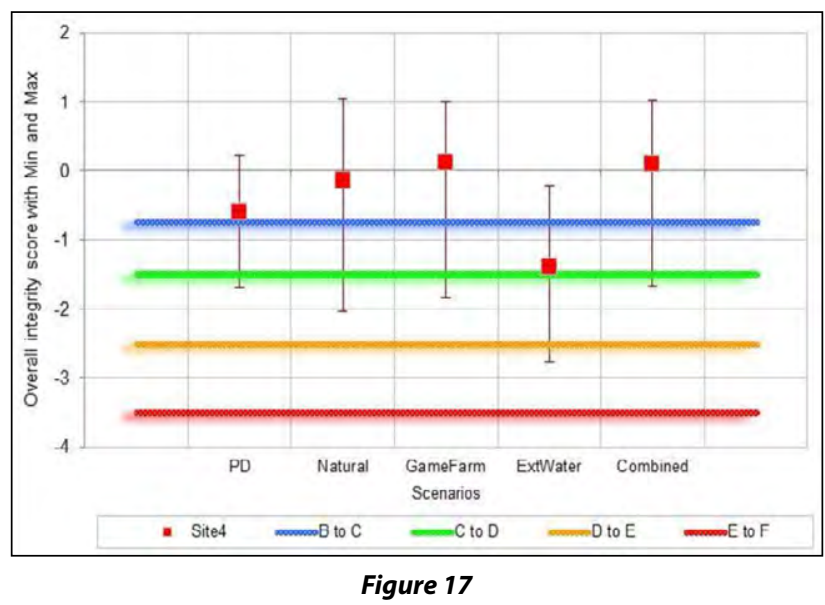

Overall integrity at Site 4 on the Mokolo River (ecosystem integrity only)

which established empirical relationships with flow have been developed should be chosen until more data is available.

The socio-economic aspect of EWRs is extremely important (Cottingham et al., 2002). A more comprehensive stakeholder process is needed to fully incorporate the socio-economic aspects into the EWRs. In non-perennial rivers, the stakeholder process is extremely important as it can provide local knowledge and data (e.g. timing of floods, location of permanent pools) for specialists to use in catchments where data is scarce. Although the stakeholder process is expensive, it is a necessity in any study on non-perennial rivers.

Due to data shortages and inaccuracies of data for nonperennial rivers, a rapid method based on catchment and readily available data, should be developed until more reliable data is available. An option is a rapid DRIFT-ARID 'LITE', which relies on a countrywide assessment of the responses to development of various types of non-perennial rivers. Broad rules could be determined on how non-perennial rivers react to development, and could be used to infer the impact of scenarios on similar river types.

It is envisaged that DRIFT-ARID and the DRIFT-ARID DSS will evolve from their current state as the underlying conceptual understanding of the functioning of non-perennial systems evolves and is tested on other rivers.

\section{ACKNOWLEDGEMENTS}

The Centre for Environmental Management and the Water Research Commission are acknowledged for supplying funds and facilities. We thank Southern Waters for assisting in the development of the DRIFT-ARID model. Both reviewers are thanked for the considerable contribution they made to the success of this article.

\section{REFERENCES}

BARKER CH (2010) Catchment geomorphology. Runoff potential unit determination. Report for Centre for Environmental Management as part of WRC Project K5/1798. WRC Report No. TT 579/13. Water Research Commission, Pretoria.

BEILFUSS RD and BROWN C (2006) Assessing Environmental Flow Requirements for the Marromeu Complex of the Zambezi Delta: Application of DRIFT Model (Downstream Response to Imposed Flow Transformations). Museum of Natural History, University of Eduardo Mondlane, Maputo, Mozambique. 
BROWN CA, PEMBERTON C and MAGOBA KN (2006) Olifants Doorn Catchment. Ecological Water Requirements Study. Final Summary Report. Prepared by Southern Waters Ecological Research and Consulting CC for DWAF. DWAF Report No. RDM/E000/MSR/01/ CON/0606. Department of Water Affairs and Forestry. Pretoria.

BROWN CA, JOUBERT AR, PEMBERTON CW, GREYLING AJ and KING JM (2008) DRIFT user manual. Volume 2: Biophysical Module for predicting overall river condition in small to medium sized rivers with relatively predictable flow regimes (incorporating updates to the DRIFT database). Water Research Commission, Pretoria.

BROWN CA and LOUW D (2011) Tools and Procedures for Resource Directed Measures. In: King J and Pienaar H (eds) Sustainable Use of South Africa's Inland Waters. WRC Report No. TT 491/11. Water Research Commission, Pretoria.

BROWN CA, JOUBERT AR, BEUSTER J, GREYLING A and KING JM (2013) DRIFT: DSS software development for integrated flow assessments: Final report and user manual. Southern Waters, Town.

BULL LJ and KIRKBY MJ (2002) Dryland river characteristics and concepts. In: Bull LJ and Kirkby MJ (eds) (2002) Dryland Rivers Hydrology and Geomorphology of Semi-Arid Channels. Wiley and Sons Ltd., Chichester.

BUNN SE and ARTHINGTON AH (2002) Basic principles and ecological consequences of altered flow regimes for aquatic biodiversity. Environ. Manage. 30 (4) 492-507. http://dx.doi.org/10.1007/ s00267-002-2737-0

COTTINGHAM P, THOMS MC and QUINN GP (2002) Scientific panels and their use in environmental flow assessment in Australia. Aust. J. Water Resour. 5 103-111.

DALLAS HF (2009) Wetland monitoring using aquatic macroinvertebrates. Technical Report 5/2009. Prepared for the Biokavango Project, Harry Oppenheimer Okavango Research Centre. University of Botswana. The Freshwater Consulting Group, University of Cape Town, Cape Town.

DICKENS CWS and GRAHAM PM (2002) The South African Scoring System (SASS) Version 5. Rapid Bioassessment Method for Rivers. Afr. J. Aquat. Sci. 27 1-10. http://dx.doi.org/10.2989/16085914.2002 .9626569

DOLLAR ESJ, BROWN CA, TURPIE JK, JOUBERT AR, NICOLSON CR and MANYAKA SM (2007) The development of the Water Resource Classification System (WRCS). Volume 1. Overview and 7-step classification procedure. CSIR Report No. CSIR/NRE/WR/ ER/2006/0187A/C. Department of Water Affairs and Forestry. Pretoria.

DWAF (DEPARTMENT OF WATER AFFAIRS AND FORESTRY, SOUTH AFRICA) (2008a) Intermediate Reserve Determination Study for the Surface and Groundwater Resources in the Mokolo Catchment, Limpopo Province: EcoClassification Report -

Volume 2. Prepared by Water for Africa and Clean Stream Biological Services. Louw, MD and Koekemoer S (eds.). RDM Report No. 26/8/3/10/14/008. Department of Water Affairs and Forestry, Pretoria.

DWAF (DEPARTMENT OF WATER AFFAIRS AND FORESTRY, SOUTH AFRICA) (2008b) Intermediate Reserve determination study for selected water resources (rivers, groundwater and wetlands) in the Limpopo Water Management Area, Limpopo. Mokolo River System: Resource Unit Delineation: Prepared by Clean Stream Biological Services and Water for Africa. Kotze PJ and Louw MD (eds). Report No. 26/8/3/10/14/006. Department of Water Affairs and Forestry, Pretoria.

DWA (DEPARTMENT OF WATER AFFAIRS, SOUTH AFRICA) (2010) Intermediate Reserve Determination Study for the surface and groundwater resources in the Mokolo Catchment, Limpopo Province: Mokolo River System: Main report. Report authored by Rivers for Africa eFlows Consulting. Report No. 26/8/3/10/14/014. Department of Water Affairs, Pretoria.

DWA (DEPARTMENT OF WATER AFFAIRS, SOUTH AFRICA) (2010a) Intermediate Reserve Determination Study for the surface and groundwater resources in the Mokolo Catchment, Limpopo Province: Ground water-surface water interaction report. Authored by Rivers for Africa eFlows Consulting. Report No. 26/8/3/10/12/013. Department of Water Affairs, Pretoria.
DWA (DEPARTMENT OF WATER AFFAIRS, SOUTH AFRICA)

(2010b) Rivers database. URL: http://www.riv.co.za/Rivers/

Application/Login.aspx? ReturnUrl=\%2fRivers\%2fApplication\%2fDe fault.aspx. (Accessed 13 March 2015).

GRAHAM DN and BUTTS MB (2005) Flexible, integrated watershed modelling with MIKE SHE. In: Singh VP and Frevert DK (eds) (2005) Watershed Models. CRC Press, Boca Raton.

HUGHES DA and HANNART P (2003) A desktop model used to provide initial estimate of the ecological instream flow requirements of rivers in South Africa. J. Hydrol. 270 167-181. http://dx.doi. org/10.1016/S0022-1694(02)00290-1

HUGHES DA (2008) Hydrological information requirements and methods to support the determination of Environmental Water Requirements in ephemeral river systems. WRC Report No. KV 205/08. Water Research Commission, Pretoria.

KING JM, BROWN CA and SABET H (2003) A scenario based holistic approach to environmental flow assessments for regulated rivers. River Res. Appl. 19 (5-6) 619-640. http://dx.doi.org/10.1002/rra.709

KING JM, BROWN CA, PAXTON BR and FEBRUARY RJ (2004) Development of DRIFT, a scenario-based methodology for environmental flow assessments. WRC Report No. 1159/1/04. Water Research Commission, Pretoria.

KLEYNHANS CJ and LOUW MD (2007) Module A: EcoClassification and EcoStatus Fetermination in River EcoClassification: Manual for EcoStatus Determination (version 2). Joint Water Research Commission and Department of Water Affairs and Forestry Report. WRC Report No. TT329/08. Water Research Commission, Pretoria

KLEYNHANS CJ and LOUW MD (2007a) Appendix A. River reach demarcation, delineation and site suitability. In: Comprehensive Reserve determination study for selected water resources (rivers, groundwater and wetlands) in the Inkomati Water Management Area, Mpumalanga. Sabie and Crocodile systems: resource unit delineation. Report No. 26/8/3/10/12/006. Department of Water Affairs and Forestry, Pretoria.

KLEYNHANS CJ, LOUW MD and MOOLMAN J (2008) Module D (Volume 2): Reference Frequency of Occurrence of Fish Species in South Africa: Manual for EcoStatus Determination (Version 2). Joint Water Research Commission and Department of Water Affairs and Forestry Report. WRC Report No. TT331/08. Water Research Commission, Pretoria.

KLEYNHANS CJ, MACKENZIE J and LOUW MD (2007) Module F: Riparian Vegetation Response Assessment Index in River Ecoclassification: Manual for Ecostatus Determination (Version 2). Joint Water Commission and Department of Water Affairs and Forestry Report. WRC Report No. TT 333/08. Water Research Commission, Pretoria.

LOUW MD, KEMPER N and BIRKHEAD A (1999) R22: Procedure for Selection Sites in Intermediate and Comprehensive Determination of the Ecological Reserve (Water Quantity Component). Resource Directed Measures for the Protection of Water Resources: River Ecosystem. Department of Water Affairs and Forestry. Pretoria.

MRC (MEKONG RIVER COMMISSION) (2006) Integrated Basin Flow Management Report Number 8: Flow-Regime Assessment. Mekong River Commission, Vientiane. Lao PDR.

O'KEEFFE JH, HUGHES DA and THARME RE (2002) Linking ecological responses to altered flows, for use in environmental flow assessments: The flow stressor-response method. Proc. Int. Ass. Theor. Appl. Limnol. 28 84-92.

PALMER R (2013) Macroinvertebrates. In: Rivers for Africa, Eflows consulting Pty Ltd. (eds) River EFR assessment, Volume 2: Fish River EFR, supporting information. Research project on environmental flow requirements of the Fish River and the Orange-Senqu River Mouth. UNDP_GEF Orange-Senqu Strategic Action Programme (Atlas Project ID 71598). ORASECOM Technical Report 28. ORASECOM.

PRUCHA RH and GRAHAM D (2012) Integrated hydrologic flow model of the Mokolo River Basin, South Africa. Specialist report for Centre for Environmental Management. University of the Free State. WRC Report No. TT579/13. Water Research Commission, Pretoria. 
PRUCHA RH, GRAHAM D, WATSON M, AVENANT MF, ESTERHUYSE S, JOUBERT A, KEMP M, KING J, LE ROUX P, REDELINGHUYS N and co-authors (2016) MIKE-SHE integrated groundwater and surface water model used to simulate scenario hydrology for input to DRIFT-ARID: the Mokolo River case study. Water SA 42 (3) 384-398.

ROSSOUW L, AVENANT MF, SEAMAN MT, KING JM, BARKER CH, DU PREEZ PJ, PELSER AJ, ROOS JC, VAN STADEN JJ, VAN TONDER GJ and co-author (2005) Environmental water requirements in non-perennial systems. WRC Report No. 1414/1/05. Water Research Commission, Pretoria.

ROWNTREE KM and VAN DER WAAL B (2012) Fluvial geomorphology specialist report. Specialist Report for WRC Project K5/1798. WRC Report No. TT579/13. Water Research Commission, Pretoria.

SCHULZE R and MAHARAJ M (2007) 50 years of daily hydroclimatic data per quaternary catchment in South Africa. School of Bioresources Engineering and Environmental Hydrology, University of KwaZulu-Natal. (CD-ROM.)

SEAMAN MT, AVENANT MF, WATSON M, KING J, ARMOUR J, BARKER CH, DOLLAR E, DU PREEZ PJ, HUGHES D, ROSSOUW L and co-authors (2010) Developing a method for determining the environmental water requirements for non-perennial systems. WRC Report No. TT 459/10. Water Research Commission. Pretoria.

SEAMAN MT, WATSON M, AVENANT MF, JOUBERT AR, KING JM, BARKER CH, ESTERHUYSE S, GRAHAM D, KEMP ME, LE ROUX PA and co-authors (2013) Testing a methodology for Environmental Water Requirements in non-perennial rivers. The Mokolo River Case Study. WRC Report No. TT579/13. Water Research Commission, Pretoria.
SEAMAN MT, WATSON M, AVENANT MF, KING JM, JOUBERT AR, BARKER CH. ESTERHUYSE S, GRAHAM D, KEMP ME, LE ROUX PA and co-authors (2016) DRIFT-ARID: A method for assessing environmental water requirements (EWRs) for non-perennial rivers. Water SA 42 (3) 356-367.

STRAHLER AN (1952) Hypsometric (area-altitude) analysis of erosional topology. Geol. Soc. Am. Bull. 63 (11) 1117-1142. http://dx.doi. org/10.1130/0016-7606(1952)63[1117:HAAOET]2.0.CO;2

STEŸN E (2008) Investigation into the reliability of the discharge records of selected gauging stations in a few non-perennial rivers in RSA. Report by Department of Water Affairs and Forestry, Northern Cape Province, for Centre for Environmental Management as part of WRC Project K5/1798. WRC Report No. TT579/13. Water Research Commission, Pretoria.

TAYLOR JC, HARDING WR and ARCHIBALD CGM (2007) A methods manual for the collection, preparation and analysis of diatom samples. Version 1.0. WRC Report No. TT 281/07. Water Research Commission, Pretoria.

THOMS MC and SHELDON F (2002) An ecosystem approach for determining environmental water allocations in Australian dryland river systems: the role of geomorphology. Geomorphology 47 153-168. http://dx.doi.org/10.1016/S0169-555X(02)00085-5

UYS MC (1998) The ecology of temporary streams in the Eastern Cape. PhD Thesis, Rhodes University, Grahamstown. 